
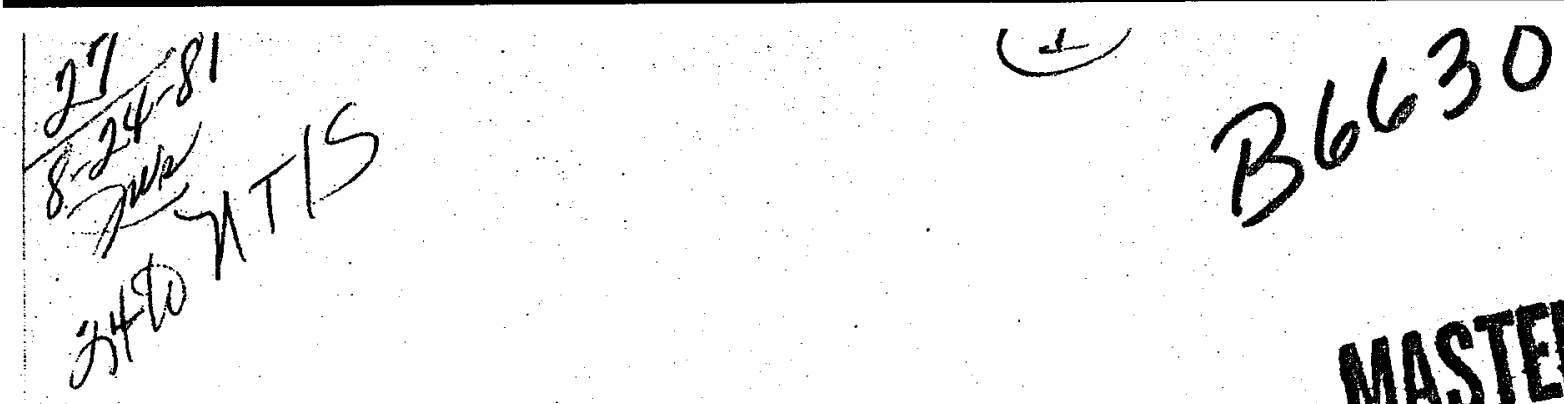

$\frac{\text { PNL-3847 }}{\text { UC-66e }}$

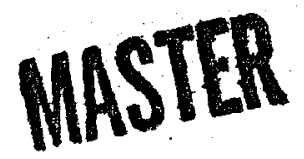

\title{
Updated Cost Estimates of Meeting Geothermal Hydrogen Sulfide Emission Regulations
}

K. D. Wells

J. W. Currie

S. A. Weakley

M. Y. Ballinger

August 1981

Prepared for the U.S. Department of Energy under Contract DE-AC06-76RLO 1830

Pacific Northwest Laboratory Operated for the U.S. Department of Energy by Battelle Memorial Institute

\section{Battelle}




\section{DISCLAIMER}

This report was prepared as an account of work sponsored by an agency of the United States Government. Neither the United States Government nor any agency Thereof, nor any of their employees, makes any warranty, express or implied, or assumes any legal liability or responsibility for the accuracy, completeness, or usefulness of any information, apparatus, product, or process disclosed, or represents that its use would not infringe privately owned rights. Reference herein to any specific commercial product, process, or service by trade name, trademark, manufacturer, or otherwise does not necessarily constitute or imply its endorsement, recommendation, or favoring by the United States Government or any agency thereof. The views and opinions of authors expressed herein do not necessarily state or reflect those of the United States Government or any agency thereof. 


\section{DISCLAIMER}

Portions of this document may be illegible in electronic image products. Images are produced from the best available original document. 


\title{
NOTICE
}

This report was prepared as an account of work sponsored by the United States Government. Neither the United States nor the Department of Energy, nor any of their employees, nor any of their contractors, subcontractors, or their employees, makes any warranty, express or implied, or assumes any legal liability or responsibility for the accuracy. completeness or usefulness of any information, apparatus, product or process disclosed, or represenis that its use would not infringe privately owned rights.

The views, opinions and conclusions contained in this report are those of the contractor and do not necessarily represent those of the United States Covernment or the United States Department of Energy.

\author{
PACIFIC NORTHWEST LABORATORY \\ operated by \\ BATTELLE \\ for the \\ UNITED STATES DEPARTMENT OF ENERGY \\ Under Contract DE-AC06-76RLO 1830 \\ Printed in the United States of America \\ Available from \\ National Technical Information Service \\ United Stat es Department of Commerce \\ 5265 Port Royal Road \\ Soringfield, Virginia 22151
}

Price: Printed Copy $\$$

Microliche $\$ 3.00$

NTIS

* Pages selting Price.

$001-025 \quad \$ 4.00$

$026-050 \quad \$ 4.50$

$\begin{array}{ll}051-075 & \$ 5.25\end{array}$

$076-100 \quad \$ 6.00$

$101-125 \quad \$ 6.50$

$126-150 \quad \$ 7.25$

$151-175 \quad \$ 8.00$

$176-200 \quad \$ 9.00$

$201-225 \quad \$ 9.25$

226-250 $\quad \$ 9.50$

251-275 $\$ \$ 10.75$

276-300 \$11.00 
PNL -3847

UC-66e

UPDATED COST ESTIMATES OF MEETING GEOTHERMAL HYDROGEN SULFIDE EMISSION REGULATIONS

\author{
K. D. Wells \\ J. W. Currie \\ S. A. Weakley \\ M. Y. Ballinger
}

August 1981

Prepared for the

U.S. Department of Energy under Contract DE-AC06-76RLO 1830

Pacific Northwest Laboratory Richland, Washington 99352

This book was prepared as an occount of work sconsored by an agency of tha United States Government. Neither the United Strtes Government nor any agency thereof, nor any of their omployes, makes any completerens or a

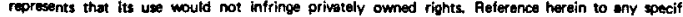

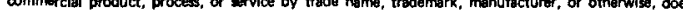

not nacossarity constitute ar imply its endorsement, racommendation. of fevoring by the United

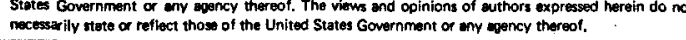



FOREWORD

Development and commercialization of hydrothermal resources for electrical energy production is recognized as a complex political, environmenta 1 , and economic undertaking. Substantial uncertainty exists concerning the degree to which the economic climate, environmental changes, and political actions will influence development and ultimate commercialization.

This research report is one of a series being prepared as part of the Department of Energy's project entitled "Economic Valuation of Geothermal Environmental Impacts." The goal of this project is to provide information and support for program planning, research, and marketing activities directed toward the commercialization of hydrothermal resources. A primary objective of this work includes developing ways to identify, estimate, and mitigate the nonmarket cost impediments to the commercialization of hydrothermal resources.

Pacific Northwest Laboratory (PNL) is conducting this project for the Department of Energy, Office of Hydrothermal Commercialization, under Contract No. AE-30-03-02. Publications from this project include:

Wells, K. D. and J. W. Currie. 1979. "Impact of $\mathrm{H}_{2} \mathrm{~S}$ Emission Abatement on Geothermal Power Costs." Proceedings, Institute of Environmental Sciences, 25th Annual Technical Meeting. Seattle, Washington.

Wells, K. D., J. W. Currie, S. A. Weakley, and M. Y. Ballinger. 1980. The Cost of Meeting Geothermal Hydrogen Sulfide Emission Regulations. PNL-2802, Pacific Northwest Laboratory, Richland, Washington.

Scott, M. J., K. D. Wells, J. W. Currie and M. J. King. 1980. An Exploratory Benefit Cost Analysis of Environmental Controls on Hydrothermal Energy. PNL-3527, Pacific Northwest Laboratory, Richland, Washington.

Wells, K. D., J. W. Currie, B. A. Price and E. A. Rogers. 1981. The Cost of Meeting Geothermal Liquid Effluent Disposal Regulations. PNL-2991, Pacific Northwest Laboratory, Richland, Washington.

Wells, K. D., J. W. Currie, S. A. Weakley and M. Y. Ballinger. 1981. Updated Cost Estimates of Meeting Geothermal Hydrogen Sulfide Emission Regulations.

PNL-3847, Pacific Northwest Laboratory, Richland, Washington.

J. W. Currie

Project Manager 

SUMMARY

To discover how to effectively increase the rate and level of hydrothermal resource utilization, the U.S. Department of Energy, Office of Hydrothermal Commercialization, initiated a study of hydrogen sulfide emission control costs. Research was conducted by the staff of Pacific Northwest Laboratory, operated for the Department of Energy by Battelle Memorial Institute.

Hydrogen sulfide $\left(\mathrm{H}_{2} \mathrm{~S}\right)$ emissions from hydrothermal resources create an odor nuisance at development sites. The cost of preventing the odor nuisance may be large and may constitute a significant economic barrier to resource comercialization under existing environmental standards.

The primary objectives of this research were to develop $\mathrm{H}_{2} \mathrm{~S}$ abatement cost functons that may be used to estimate $\mathrm{H}_{2} \mathrm{~S}$ emission control costs and to prepare a case study of emission control costs at a specific known geothermal resource area (KGRA). $\mathrm{H}_{2} \mathrm{~S}$ abatement costs were hypothesized to depend on several variables, including $\mathrm{H}_{2} \mathrm{~S}$ concentrations, treatment process removal efficiencies, and environmental standards. Contacts with resource developers and utilities and literature reviews both indicated that $\mathrm{H}_{2} \mathrm{~S}$ concentrations may range from near zero to over 500 parts per million by weight $\left(500 \mathrm{ppm}_{W}\right)$ in the flashed-steam fraction of the fluid. Removal efficiencies ranged from 50 to $99 \%$ and environmental standards varied widely.

Regulations exist only at the state level of government, although the Environmental Protection Agency (EPA) has promulgated federal guidelines. Transition from an ambient concentration standard to an emission limitation was a regulatory trend identified that may solve the problem of estimating the $\mathrm{H}_{2} \mathrm{~S}$ abatement level required at a given site.

$\mathrm{H}_{2} \mathrm{~S}$ emission abatement processes considered feasible for airborne emission control included two upstream and two downstream treatment techniques. From literature describing the technical aspects of the processes, individual treatment cost functions were developed and then used in a case study to estimate the costs that may be encountered when controlling $\mathrm{H}_{2} \mathrm{~S}$ emissions at 
one site. Treatment costs include estimates of certain fixed charges and overheads that normally apply to long-lived capital investment projects of similar nature.

A case study of $\mathrm{H}_{2} \mathrm{~S}$ emission control costs expected at the Valles Caldera KGRA in New Mexico was developed in this report. The resource has a relatively high $\mathrm{H}_{2} \mathrm{~S}$ concentration in the raw-flashed steam (250 to 500 $\left.\mathrm{ppm}_{\mathrm{w}}\right)$. Ambient environmental standards for $\mathrm{H}_{2} \mathrm{~S}$ are relatively stringent in this part of New Mexico $\left(3 \mathrm{ppm}_{\mathrm{w}}\right)$, although a partial waiver may be granted for the Valles Caldera KGRA. For abatement levels up to $90 \%$ of potential $\mathrm{H}_{2} \mathrm{~S}$ emissions, the Stretford process appears to be the most cost-effective control system. Application of the process would cost an estimated minimum of $1.78 \mathrm{mills}$ per $\mathrm{kWh}$ or $\$ 1.3 \mathrm{million}$ per year in January 1980 dollars for a 110 MWe plant.

To achieve higher levels of emission control, up to $97 \%$ abatement of potential $\mathrm{H}_{2} \mathrm{~S}$ emissions, the EIC process appears to be the most costeffective system. As a substitute for the Stretford process it would achieve a maximum of $97 \%$ abatement at a cost of 3.55 mills per $\mathrm{kWh}$, or $\$ 2.6$ million per year in January 1980 dollars for a 110 MWe plant.

The incremental cost of achieving the extra $8 \%$ control is 1.77 mills per $k W h$, a $100 \%$ increase. When the efficient allocation of society's scarce resources is considered, the value of the odor prevention benefits realized by the use of abatement systems must be weighed against the costs of those systems.

Currently, the value of preventing the $\mathrm{H}_{2} \mathrm{~S}$ odor nuisance at hydrothermal resources is not known, but should be developed and used as the basis for assessing the net benefits of alternative levels of $\mathrm{H}_{2} \mathrm{~S}$ emission abatement to society. 
Pacific Northwest Laboratory would like to acknowledge the contributions of Garratt Sharp, Larry Kruml and, and Carl Weinberg of Pacific Gas and Electric Company at the Geysers; Gerald Katz of the San Francisco DOE Operations Office; Joel Robertson of Union 011 Company, Los Angeles, California; William Dyer of the EIC Corporation, and John Wilson of Dow Chemical Company, Freeport, Texas. PNL researchers who participated in reviewing earlier drafts include Linda L. Fassbender and $\mathrm{Cl}$ arence H. Bloomster. Word processing was coordinated by Ruth Keefe and Shari Loeber. Editing and proofreading was managed by Vicki Lee. 


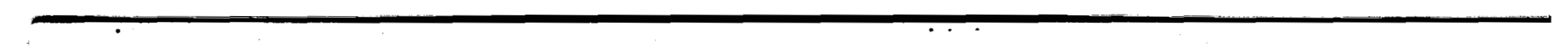

$\mathcal{U}$ 


\section{CONTENTS}

FOREWARD

i i i

SUMMARY

ACKNOWLEDGMENTS

vii

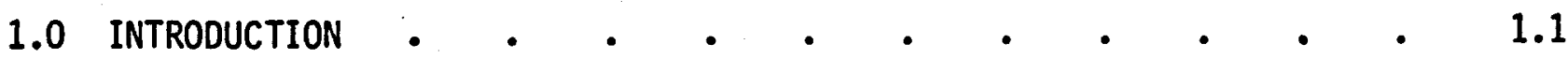

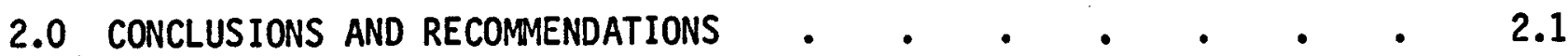

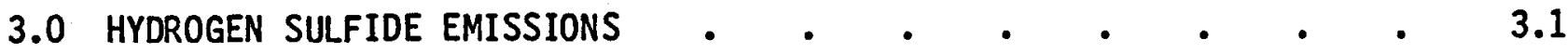

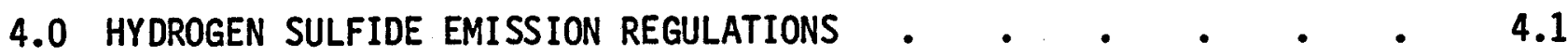

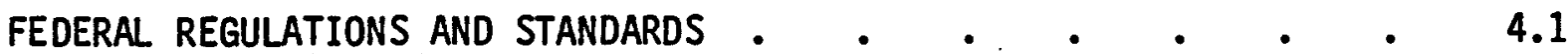

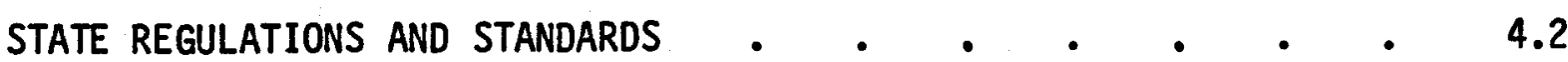

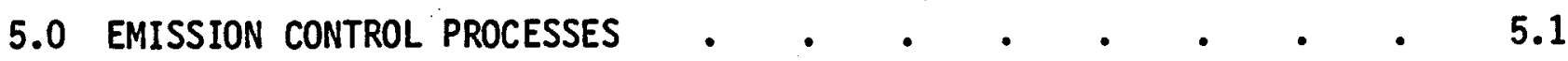

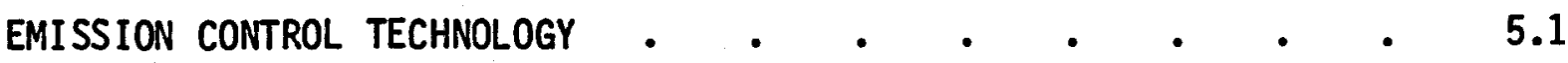

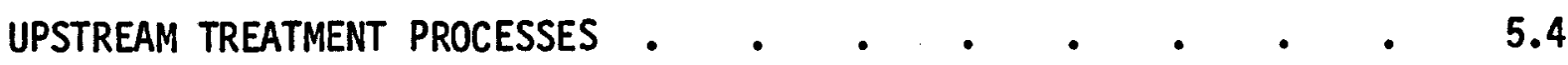

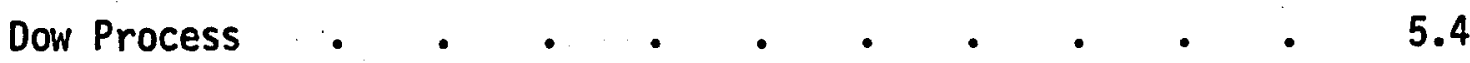

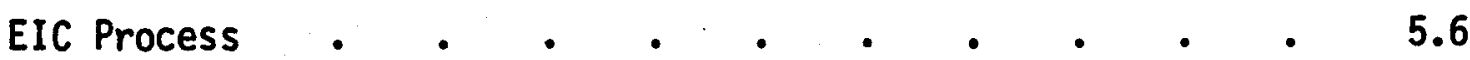

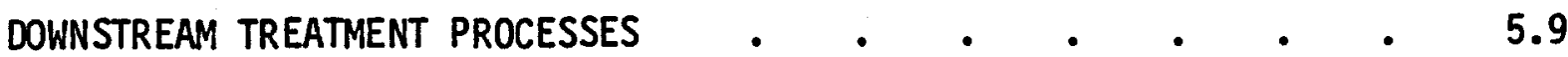

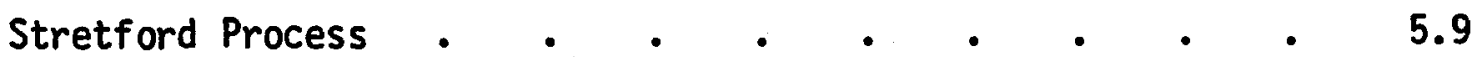

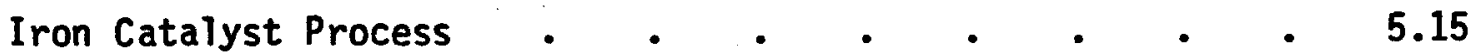

COMPARATIVE PROCESS SUMMARY $. \quad . \quad . \quad . \quad . \quad . \quad . \quad . \quad 5.17$

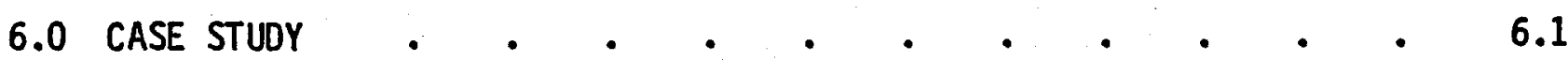

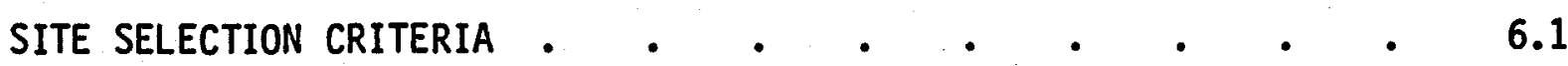

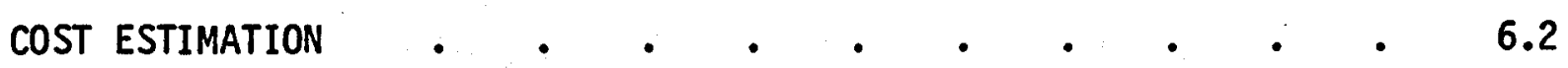

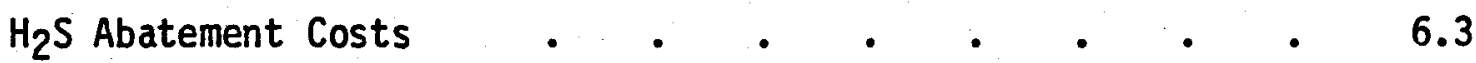

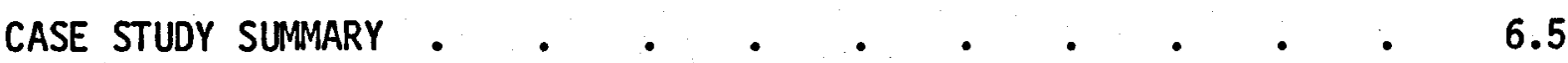

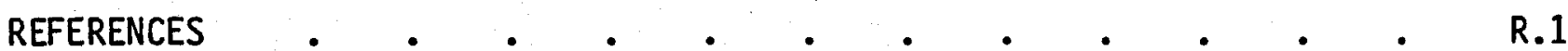


APPENDIX A - RESERVOIR GEOCHEMISTRY SUMMARY - • • • • •

A.1

APPENDIX B - HYDROGEN SULFIDE CONTROL COST FUNCTIONS

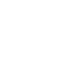

APPENDIX $\mathrm{C}-\mathrm{H}_{2}$ ABATEMENT COSTS

APPENDIX D - COST ESTIMATION METHODOLOGY 


\section{FIGURES}

$5.1 \mathrm{H}_{2} \mathrm{~S}$ Treatment Process Locations . . . . . . . $\quad$. 5.3

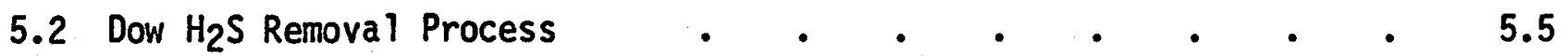

5.3 EIC Hydrogen Sulfide Removal Process with
Regeneration by Leaching . • . . . . . . . . 5.7

5.4 Modified System Cycle for Using Surface Condensers at The
Geysers Power Plant . . . . . . 5.10

5.5 Typical Flow Diagram of Stretford Process at The
Geysers

5.6 Mass Balance for 27 MWe Plant with Surface Condenser
and Stretford Plant. . . . . . . . 5.14

5.7 Iron Catalyst $\mathrm{H}_{2} \mathrm{~S}$ Removal Process . . . . . . 5.16

6.1 Comparative $\mathrm{H}_{2} \mathrm{~S}$ Abatement Costs for Baca, New Mexico . . $\quad$. 6.4

\section{TABLES}

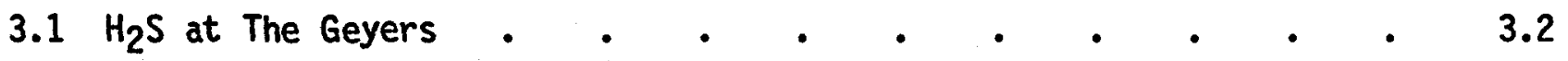

4.1 State $\mathrm{H}_{2} \mathrm{~S}$ Standards for Hydrothermal Developments . . . 4.2

$5.1 \mathrm{H}_{2} \mathrm{~S}$ Control Technology Șumary . $\quad . \quad$. $\quad . \quad$. 5.19

6.1 Baca, New Mexico Resource Description . . . . . . . 6.2

A.1 Reservoir Geochemistry Surmary . . . . . . . A.1

C.1 Hydrogen Sulfide Abatement Costs • • • • • • • • • C C.1

D.1 Variables for Cost Estimation . • • • • • • • • • $\quad$ • 0.4 


\subsection{INTRODUCTION}

Geothermal resource development may lead to new or increased emissions of hydrogen sulfide $\left(\mathrm{H}_{2} \mathrm{~S}\right)$ and other environmental changes that will be subject to a range of regulation and control requirements. This research provides a means of estimating the cost of hydrogen sulfide $\left(\mathrm{H}_{2} \mathrm{~S}\right)$ emission control.

This study was designed to derive $\mathrm{H}_{2} \mathrm{~S}$ emission abatement cost functions and illustrate the cost of $\mathrm{H}_{2} \mathrm{~S}$ emission abatement at a hydrothermal site.

Four tasks were undertaken to achieve the study's objectives:

- document the release of $\mathrm{H}_{2} \mathrm{~S}$ associated with geothermal development

- review $\mathrm{H}_{2} \mathrm{~S}$ environmental standards

- develop functional relationships that may be used to estimate the most cost-effective available $\mathrm{H}_{2} \mathrm{~S}$ abatement process

- use the cost functions to generate abatement cost estimates for a specific site.

Section 2.0 presents the conclusions and recommendations derived from the research. Section 3.0 discusses the definition of the term "impacts" as used in this research and provides current estimates of the highest expected $\mathrm{H}_{2} \mathrm{~S}$ concentrations of in geothermal reservoirs. Regulations governing $\mathrm{H}_{2} \mathrm{~S}$ emissions are reviewed in Section 4.0, while Section 5.0 contains a review of $\mathrm{H}_{2} \mathrm{~S}$ control technology and a sumary of the control cost functions. A case study is presented in Section 6.0 to illustrate $\mathrm{H}_{2} \mathrm{~S}$ abatement costs at the Baca KGRA in New Mexico.

Information presented in this document is intended to serve as an aid to the Department of Energy in research, development, and demonstration allocation decisions. 


\subsection{CONCLUSIONS AND RECOMMENDATIONS}

A review of $\mathrm{H}_{2} \mathrm{~S}$ emissions, environmental regulations, and the cost of $\mathrm{H}_{2} \mathrm{~S}$ emission abatement resulted in the following conclusions:

- $\mathrm{H}_{2} \mathrm{~S}$ gas is a potential emission from at least $25 \%$ of the identified high-temperature hydrothermal convection systems in the western United States.

- Regulatory compliance are costs positively related to the concentration of $\mathrm{H}_{2} \mathrm{~S}$ in the raw geothermal fluid, the fluid flow rate, and the abatement level achieved at the geothermal site.

- The magnitude of $\mathrm{H}_{2} \mathrm{~S}$ abatement costs will depend on the control level required to achieve regulatory compliance.

- For the Baca, New Mexico, case study: 1) the EIC $\mathrm{H}_{2} \mathrm{~S}$ removal process appears to be the most cost effective of the currently available abatement processes when high levels of emission control must be achieved. The process is expected to achieve $97 \%$ abatement of $\mathrm{H}_{2} \mathrm{~S}$ emissions. 2) $\mathrm{H}_{2} \mathrm{~S}$ abatement efforts may increase power costs for flashed-steam systems at the site by approximately 3.55 mills per $\mathrm{kWh}$, in January 1980 dollars.

- Without an investigation of the incremental benefits of $\mathrm{H}_{2} \mathrm{~S}$ emission control, the most desirable emission abatement level for hydrothermal resources cannot be specified.

The results of this study indicate the need for additional research in the following areas:

- investigate the factors determining the value of reducing or eliminating the $\mathrm{H}_{2} \mathrm{~S}$ odor nuisance at geothermal sites

- estimate the net benefits and costs to society of alternative $\mathrm{H}_{2} \mathrm{~S}$ abatement levels at hydrothermal sites. 


\subsection{HYDROGEN SULFIDE EMISSIONS}

Hydrothermal resource development will change the environment with three types of impacts: 1) airborne emissions, 2) waterborne emissions, and 3) land use impacts. This report deals specifically with hydrogen sulfide $\left(\mathrm{H}_{2} \mathrm{~S}\right)$ airborne emissions. A large body of literature that describes the sources of $\mathrm{H}_{2} \mathrm{~S}$ emissions has been developed but little has been done previously to develop functions for estimating abatement costs (Axtman 1975; Defferding et a1. 1978; Futures Group 1975; Maritin et a1. 1978; Midwest Research Institute 1978; Sung et al. 1977; EPA 1978; Wapora, Inc. 1976).

Unlike waterborne effluents and land impacts, the control processes for $\mathrm{H}_{2} \mathrm{~S}$ abatement are remarkably similar in design and application between liquid- and steam-dominated resources and conversion systems. Data from $\mathrm{H}_{2} \mathrm{~S}$ research at the Geysers are expected to be directly applicable to control situations that may arise on liquid-dominated resources, primarily because the conversion technology used on liquid-dominated systems may be the same as the technology used on vapor-dominated resources (flashed steam). The process flows and conditions may be sufficiently similar to allow the use of common control technology.

$\mathrm{H}_{2} \mathrm{~S}$ concentrations at hydrothermal resources vary a great deal, even among wells on the same site. At The Geysers recorded $\mathrm{H}_{2} \mathrm{~S}$ concentrations in the resource steam have varied between wells by a factor of ten, from approximately $50 \mathrm{ppm}_{\mathrm{W}}$ to well over $500 \mathrm{ppm}_{\mathrm{w}}$.

August 1978 measurements of $\mathrm{H}_{2} \mathrm{~S}$ in geothermal steam at The Geysers were reported by Garratt Sharp of PG\&E and are presented in Table 3.1. Concentrations of $\mathrm{H}_{2} \mathrm{~S}$ in the raw steam vary from $51 \mathrm{ppm}_{\mathrm{w}}$ at Unit 9 to $451 \mathrm{ppm}_{\mathrm{w}}$ at power-generating Unit 3. Liquid-dominated systems also exhibit considerable variability in $\mathrm{H}_{2} \mathrm{~S}$ concentrations. Information for the Baca, New Mexico, KGRA, chosen for evaluation as a case study in this report, indicates that $\mathrm{H}_{2} \mathrm{~S}$ concentration in the raw steam may vary from $290 \mathrm{ppm}_{w}$ to over $560 \mathrm{ppm}_{\mathrm{W}}$ (Cosner 1977). The expected range of $\mathrm{H}_{2} \mathrm{~S}$ is illustrated in Appendix $A$ along with currently available geochemical data for several 
TABLE 3.1. $\mathrm{H}_{2} \mathrm{~S}$ at The Geyers

\begin{tabular}{|c|c|c|c|c|c|c|c|c|c|c|c|}
\hline Unit Number & 1 & 2 & 3 & 4 & 5 & 6 & 7 & 8 & 9 & 10 & 11 \\
\hline $\mathrm{H}_{2} \mathrm{~S}$ ppm $_{w}$ & 272 & 163 & 451 & 390 & 329 & 372 & 373 & 113 & 51 & 66 & 338 \\
\hline
\end{tabular}

additional high-temperature hydrothermal convection systems in the western United States. As many as $25 \%$ of the high-temperature KGRAs may have $\mathrm{H}_{2} \mathrm{~S}$ concentrations significantly greater than zero. 


\subsection{HYDROGEN SULFIDE EMISSION REGULATIONS}

Hydrothermal resource development at KGRAs having significant $\mathrm{H}_{2} \mathrm{~S}$ concentrations will be subject to regulatory constraints at both the state and federal level. The following sections sumarize several $\mathrm{H}_{2} \mathrm{~S}$ emission regulations and ambient standards at the state and federal levels.

\section{FEDERAL REGULATIONS AND STANDARDS}

The Clean Air Act of 1977 is the most significant federal regulation influencing airborne emissions of $\mathrm{H}_{2} \mathrm{~S}$ from hydrothermal resources. The Act describes the procedure to be used to establish emission limitations at the federal leve1. Numerical emission standards do not yet exist at the federal level for $\mathrm{H}_{2} \mathrm{~S}$ emissions. States may therefore establish their own individual standards without having to consider federal minimum ambient standards.

The procedure for establishing a federal minimum ambient standard for $\mathrm{H}_{2} \mathrm{~S}$ abatement requires the following steps:

1) scientific study of the effect that ambient $\mathrm{H}_{2} \mathrm{~S}$ concentrations have on human health and welf are

2) promulgation of a national primary standard (to protect human health) and a national secondary standard (to protect human welfare).

These standards may be either ambient standards, which are usually regarded as goals or targets to achieve, or they may be emission limitations, which are first calculated and then set at levels that will theoretically permit the ambient air quality standards to be achieved. Once an ambient standard (i.e. goal or target) is set at the federal leve1, the Clean Air Act requires the individual states to establish an emission standard that will enable the state to achieve the ambient standard. Emission limitation standards at the state level are therefore the regulatory device that resource developers will most likely have to deal with. 


\section{STATE REGULATIONS AND STANDARDS}

Although no federal ambient standard exists for $\mathrm{H}_{2} \mathrm{~S}$, some states have developed regulations governing $\mathrm{H}_{2} \mathrm{~S}$ emissions and ambient $\mathrm{H}_{2} \mathrm{~S}$ concentrations. This has been largely occurring in states such as California and New Mexico, which have hydrothermal resource developments that either create or have the potential to create an $\mathrm{H}_{2} \mathrm{~S}$ odor nuisance. The regulations are typically targeted to prevent or eliminate the odor nuisance, mainly by setting ambient standards at the odor detection threshold level for $\mathrm{H}_{2} \mathrm{~S}$, which may vary in humans anywhere from $0.002 \mathrm{ppm}_{w}$ up to $0.030 \mathrm{ppm}_{\mathrm{w}}$ (EPA 1977).

Four states have ambient air standards applicable to $\mathrm{H}_{2} \mathrm{~S}$ (California, Montana, New Mexico and Wyoming) and two have emission standards (Nevada and Texas). These states and the sumarized standards are presented in Table 4.1 below.

TABLE 4.1. State $\mathrm{H}_{2} \mathrm{~S}$ Standards for Hydrothermal Developments

\begin{tabular}{ll} 
& \multicolumn{1}{c}{ Ambient Standard } \\
\cline { 2 - 2 } California & $0.030 \mathrm{ppm}_{\mathrm{w}}$ as maximum; \\
Montana & $0.050 \mathrm{ppm}_{\mathrm{w}} ; 1 / 2$ hour average \\
& not to be exceeded more than \\
& twice per year, and 0.030 \\
& ppmw $1 / 2$ hour average not \\
& to be exceeded more than twice \\
& per 5 consecutive days
\end{tabular}

Nevada

$10 \mathrm{lbs} / \mathrm{hr}$
New Mexico Range from $0.003 \mathrm{ppmw}_{\text {to }}$ $0.100 \mathrm{ppm}_{\mathrm{w}} ; 1 / 2$ hour average within certain regions.
Texas
$0.080 \mathrm{ppm}_{\mathrm{w}} ; 1 / 2$ hour up to $0.120 \mathrm{ppm}_{\mathrm{w}} ; 1 / 2$ hour depend- ing on down wind 1 and use practices

Wyoming identical to Montana standard

Source: EPA 1978.

175 grams per MW hr on 1 hour average new units from January 1, 1979 
The ambient standards range from $0.003 \mathrm{ppm}_{\mathrm{w}}$ in New Mexico, which has the most stringent of the state standards, to $0.120 \mathrm{ppm}_{\mathrm{w}}$ in Texas, which has the most lenient standards. Emission 1 imitations range from 10 pounds per hour per installation in Nevada to $175 \mathrm{gm}$ per MWh $(\sim 20 \mathrm{lb} / \mathrm{hr}$ for a 50 MWe facility) in California (Air Resources Board 1978).

Absolute emission regulations (e.g. ARB $175 \mathrm{gm} / \mathrm{MWh}$ ) appear to offer an alternative to the problem facing developers and regulators in setting standards. Regulators have the dual goal of protecting the public health and welfare at a minimum cost to society. By setting absolute limitations, regulators will enable geothermal developers to identify the control processes required to achieve regulatory compliance. At the same time, the cost of monitoring ambient levels may be reduced for regulatory agencies. 


\subsection{EMISSION CONTROL PROCESSES}

Hydrogen sulfide is the primary airborne emission resulting from geothermal resource development and presently existing in sufficient concentrations to require control. The techniques available for $\mathrm{H}_{2} \mathrm{~S}$ emissions control are sumarized in this chapter. Abatement cost functions for these processes can be found in Appendix B.

\section{EMISSION CONTROL TECHNOLOGY}

Hydrogen sulfide occurs both in a gaseous form in geothermal steam and in a dissolved form in the steam condensate and raw geothermal fluids. Therefore, emission control processes may be applied to these gaseous or liquid streams within the facility.

Numerous processes exist or are being developed for control of $\mathrm{H}_{2} \mathrm{~S}$ emissions. Several have actually been demonstrated in conjunction with geothermal energy conversion systems. Much of the airborne emission control process development and operation has been conducted at The Geysers. Abatement processes developed there are expected to be directly transferrable to liquid hydrothermal geothermal resources.

Two basic types of treatment options exist: upstream treatment, which removes $\mathrm{H}_{2} \mathrm{~S}$ from the geothermal fluid before it passes through the turbine, and downstream treatment, which treats $\mathrm{H}_{2} \mathrm{~S}$ after it has passed through the turbine. Five such $\mathrm{H}_{2} \mathrm{~S}$ emission control techniques are being developed for potential application to geothermal plants:

Upstream Treatment

1. Dow Process

2. EIC Process

Downstream Treatment

3. Stretford Process

4. Peroxide Condensate Treatment Process

5. Iron Catalyst Process 
These processes typically generate elemental sulfur precipitates that may be pure enough to be marketable. According to Garratt Sharp of PG\&E, sulfur sludges from $\mathrm{H}_{2} \mathrm{~S}$ treatment processes at The Geysers have historically been disposed of in a solid-waste landfill. Final sludge disposal may also be accomplished by 1) settling in a sealed leak-proof evaporative basin, or 2) injection with other liquid wastes and cooling system waters into a subsurface reservoir. Each treatment and disposal option has its own mix of benefits and costs that will vary between sites. Several of the techniques use regenerable catalysts. Each process would be applied at a different location within the power generation cycle. Some or all of the processes could be used in a complementary manner to achieve higher levels of emission control.

Figure 5.1 shows the location of each process in the power generation cycle. The Dow process is located on the fluid transport lines before the flashing unit. The EIC process is applied to the flashed-steam fraction only and immediately precedes the turbine. The Stretford process is applied downstream to the noncondensible gases released from the steam condensers. The Peroxide Condensate Treatment process is applied only to the fraction of the steam that condenses into the cooling system and is intended for use only with surface contact condensers. The Iron Catalyst process is applied downstream of the turbine on the entire liquid cooling system. Noncondensible gases are routed from the direct contact condenser to the cooling tower for scrubbing when the Iron Catalyst process is used.

The upstream or pretreatment processes are desirable because of their ability to 1) reduce turbine blade stress corrosion cracking and sulfide scaling caused by the presence of $\mathrm{H}_{2} \mathrm{~S}$, and 2) reduce $\mathrm{H}_{2} \mathrm{~S}$ emissions during steam stacking. (a) The downstream processes may achieve equivalent levels of abatement, but cannot reduce $\mathrm{H}_{2} \mathrm{~S}$ emissions during turbine outages.

Escape of gases during well and pipeline venting is not subject to the same control requirements as are continuous emissions. More efficient

(a) Steam stacking occurs when one turbine in a multi-turbine generating station is down for repairs and the steam is vented. 


\section{C}

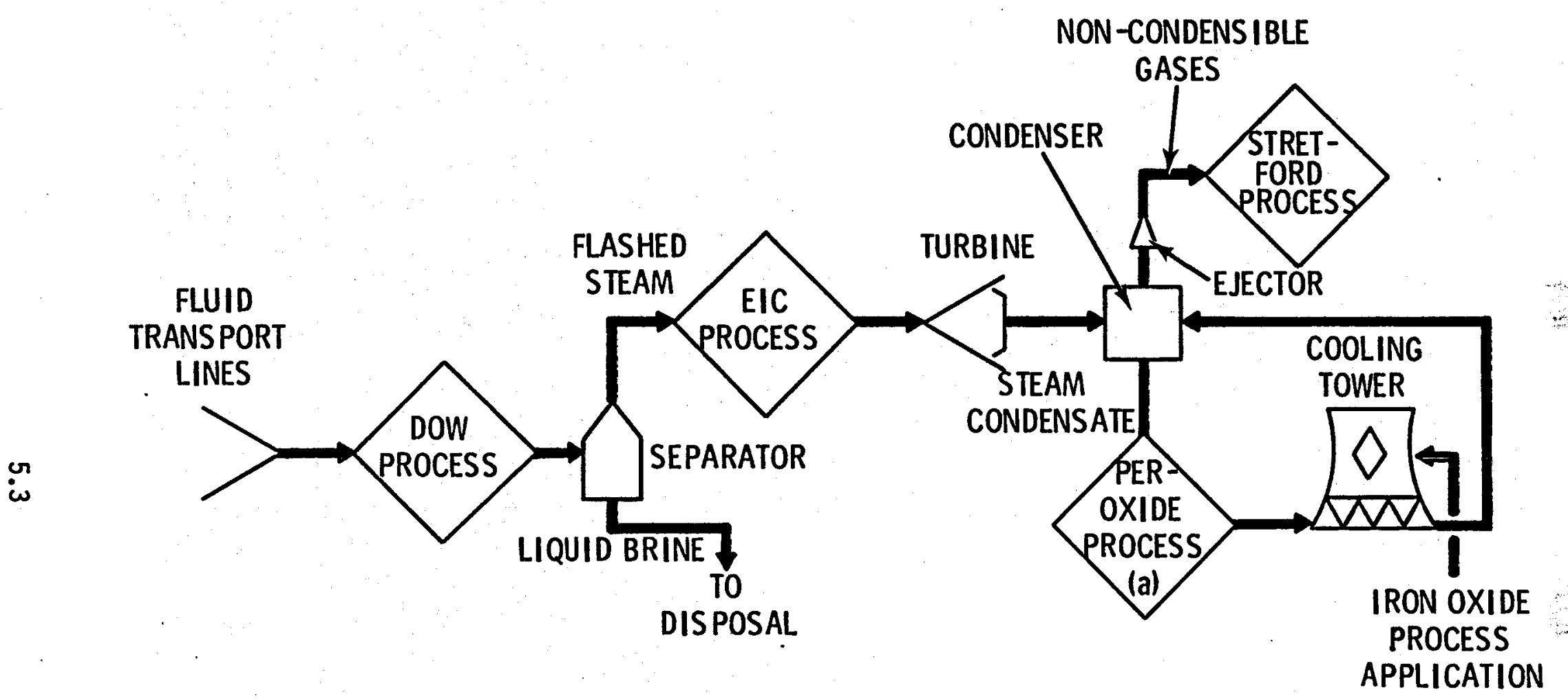

FIGURE 5.1. $\mathrm{H}_{2} \mathrm{~S}$ Treatment Process Locations

(a) Used only in conjunction with surface contact condensers and the Stretford Process. 
collection and treatment systems may need to be developed further to control these emissions. Currently, the use of hydrogen peroxide $\left(\mathrm{H}_{2} \mathrm{O}_{2}\right)$ in a manner similar to the Dow Process is the only process identified as technically feasible for controlling wellhead emissions (Martin et al. 1978; White et al. 1977).

For each available control technique the following data will be presented:

- system description

- removal efficiency

- control cost factors.

Each process has a typical complement of fixed and variable costs. Using the cost functions presented in Appendix $B$ for each process, a discounted cash flow methodology was used in a case study to estimate the levelized annual life cycle costs of $\mathrm{H}_{2} \mathrm{~S}$ abatement. These costs are tabulated in Appendix $\mathrm{C}$ and presented in the case study in Section 6.0. The discounted cash flow methodology is presented in Appendix $D$.

UPSTREAM TREATMENT PROCESSES

Dow Process

System Description

The Dow process, shown in Figure 5.2, is applicable to the treatment of $\mathrm{H}_{2} \mathrm{~S}$ dissolved in the brine of liquid-dominated resources. With this system aqueous or gaseous $\mathrm{H}_{2} \mathrm{~S}$ is oxidized at the wellhead by the injection of either oxygen $\left(\mathrm{O}_{2}\right)$ or $\mathrm{H}_{2} \mathrm{O}_{2} \cdot \mathrm{H}_{2} \mathrm{O}_{2}$ is pumped from storage, through a flow controller into the fluid lines, into the packed column and then to the corrosion monitor. The geothermal fluids are then sent to the turbogenerator for power production.

To assure complete reaction of $\mathrm{H}_{2} \mathrm{~S}$ with the oxidants, a packed-column reaction vessel is designed into the system. Initial evidence indicates that the packed-column system is more cost-effective than using in-line mixers (EPA 1978). Although the piping downstream of the column can be mild steel, the section upstream of the tower must be lined (e.g. with teflon) to resist the higher brine corrosivity associated with injection of oxidants. Bob Southard 


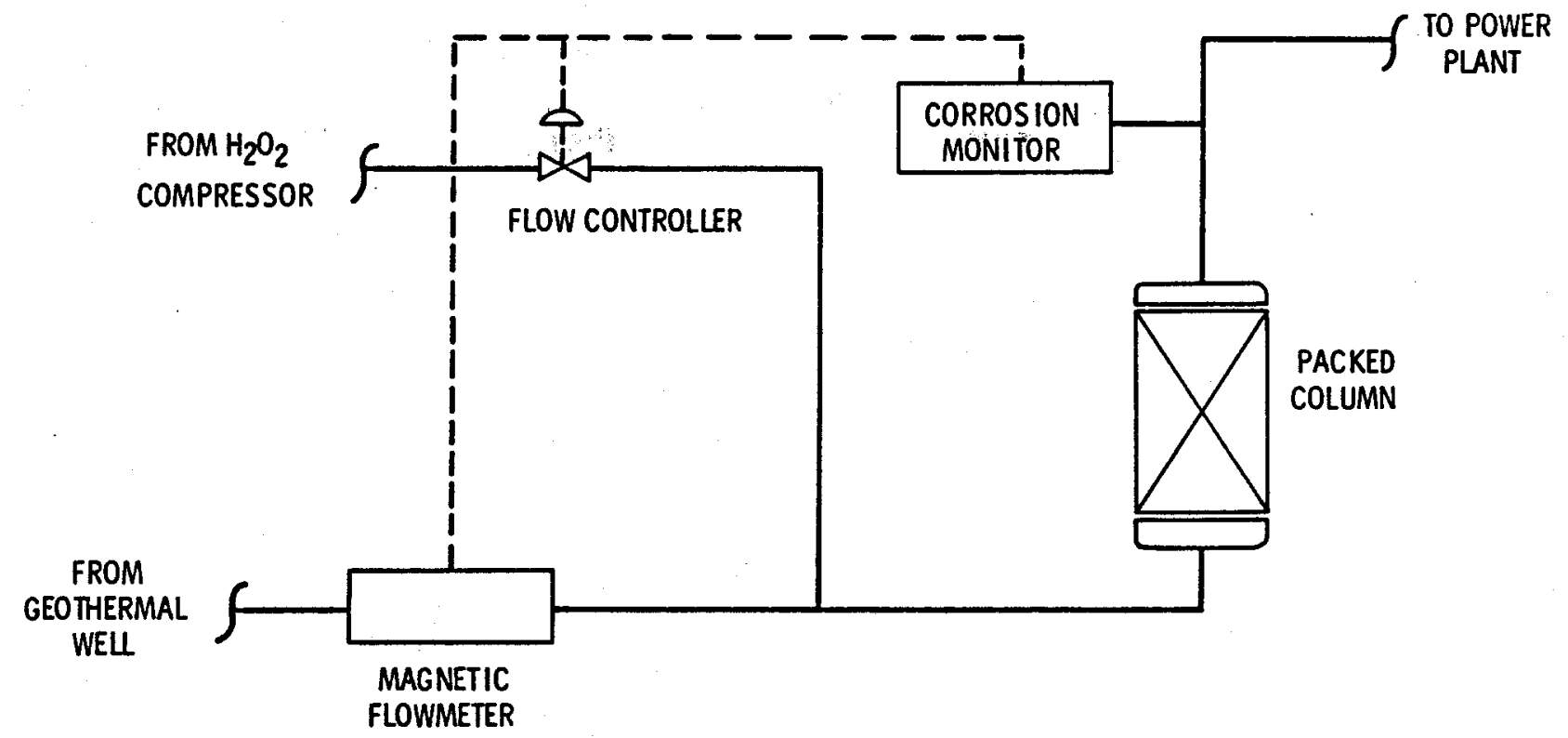

$---\div--\ldots$ FLOW CONTROL AND MONITORING FLUID FLOW

FIGURE 5.2. Dow $\mathrm{H}_{2} \mathrm{~S}$ Removal Process (EPA 1978)

of Dow Chemical in Freeport, Texas, reports that using $\mathrm{O}_{2}$ instead of $\mathrm{H}_{2} \mathrm{O}_{2}$ will allow the process to achieve $95 \%$ or higher scrubbing efficiency on $\mathrm{H}_{2} \mathrm{~S}$ in liquid streams. The process' removal efficiency falls dramatically when used on two-phase flow. John Wilson, also of the Dow Chemical, reports that removal efficiencies can be maintained in excess of $95 \%$ when either steam or two-phase flow is encountered by substituting $\mathrm{H}_{2} \mathrm{O}_{2}$ for $\mathrm{O}_{2}$ as the oxidizing agent in the process. Until downhole pump technology is perfected, geothermal fluid flow will be predominantly two-phase flow. Mr. Southard indicated that substituting $\mathrm{H}_{2} \mathrm{O}_{2}$ for $\mathrm{O}_{2}$ will achieve sufficient abatement of $\mathrm{H}_{2} \mathrm{~S}$ emissions (93\% or more) on two-phase flow to warrant its consideration as the primary chemical input for the oxidation of $\mathrm{H}_{2} \mathrm{~S}$ by the Dow process.

Removal Efficiency

Numerous laboratory scale tests that attempted to duplicate geothermal conditions have been conducted. Removal efficiencies have ranged from 90 to $100 \%$ of total $\mathrm{H}_{2} \mathrm{~S}$ produced (Midwest Research Institute 1978; EPA 1978). For 
purposes of this report, the $\mathrm{H}_{2} \mathrm{O}_{2}$ process will be evaluated assuming an average control efficiency of $96 \%$ under operating conditions. The oxygenation process will not be evaluated because of its limited applicability to the two-phase flow expected from liquid-dominated geothermal resources in the near future.

\section{Control Cost Factors}

Purchased equipment costs for the Dow process are primarily a function of brine flow rates. Size of piping and packed columns is determined by the fluid flow rate. Operating costs depend on actual $\mathrm{H}_{2} \mathrm{~S}$ flow rates. Waste disposal is assumed to be achieved by solid-waste landfilling. Values of the parameters used for cost estimation can be found in Appendix B.

\section{EIC Process (a)}

\section{System Description}

The EIC system is being developed for the treatment of the steam fraction of the geothermal fluid flow ahead or upstream of the turbine. The system cannot treat $\mathrm{H}_{2} \mathrm{~S}$ dissolved in the brine in its aqueous state. Figure 5.3 illustrates the EIC process designed with regeneration of catalysts by leaching.

In the EIC process the flashed geothermal steam is first passed through a centrex separator that removes all large particles. The steam is then introduced to the $\mathrm{H}_{2} \mathrm{~S}$ scrubbing unit, shown in the upper left of Figure 5.3, where it passes through the scrubbing towers and exits again as cleaned steam. A scrubbing solution containing copper sulfate $\left(\mathrm{CuSO}_{4}\right)$ and ammonium sulfate $\left(\mathrm{NH}_{4}\right)_{2} \mathrm{SO}_{4}$ is used to precipitate sulfide solids from the raw steam into a purge slurry. Proper maintenance of the scrub solution pH helps ensure sufficient copper concentration to promote high removal efficiency. Following scrubbing, the steam passes through a water-washed demister for removal of any

(a) Bill Dyer of the EIC Corp. reports that his company's $\mathrm{H}_{2} \mathrm{~S}$ abatement process has been named the "CUPROSUL process." However, throughout th is document it is referred to as the "EIC process". 


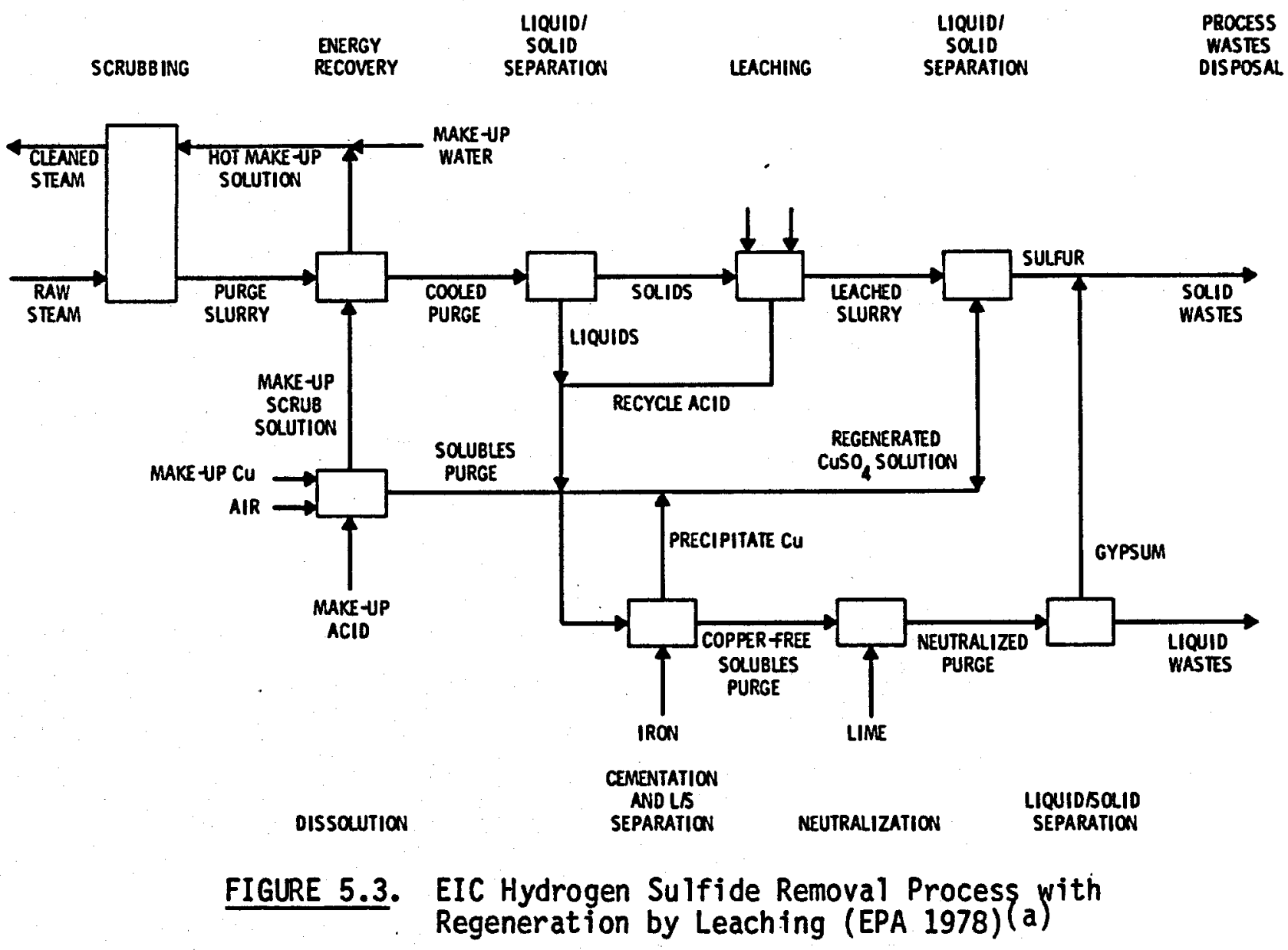

(a) Arrows indicate direction of fluid flows.

residual scrub solution. The purge slurry is then separated into solid wastes and liquid wastes. The regenerated $\mathrm{CuSO}_{4}$ solution is returned to the scrubbing towers for reuse.

At The Geysers the end product of the EIC process, ammonium sulfate, has been mixed with cooling tower water and injected underground during developmental testing (Sung et al. 1977). At sites where injection is either not permitted, not technically feasible, or less costly, the $\left(\mathrm{NH}_{4}\right)_{2} \mathrm{SO}_{4}$ may either be placed in solid-waste landfills or reclaimed for fertilizer manufacture. 


\section{Removal Efficiency}

The EIC process was field-tested in December of 1976 at The Geysers ' Unit 7. Efficiencies were generally over 97\%. In addition to $\mathrm{H}_{2} \mathrm{~S}$, almost $80 \%$ removal of ammonia $\left(\mathrm{NH}_{3}\right)$ and boric acid $\left(\mathrm{H}_{3} \mathrm{BO}_{3}\right)$ was achieved. This removal rate is significant because EPA has identified these two effluents as toxic to fauna and flora, respectively, and high on the list of potentially regulated geothermal emissions (EPA 1978). According to a recent research report (EIC 1976), at least $97 \%$ of the $\mathrm{H}_{2} \mathrm{~S}$, along with slightly lesser amounts of $\mathrm{NH}_{3}, \mathrm{H}_{3} \mathrm{BO}_{3}$, rock dust, and other materials, are removed from the steam before it enters the turbine. Recent field tests at The Geysers demonstrated that $\mathrm{H}_{2} \mathrm{~S}$ removal efficiencies of $99.9 \%$ can be achieved with the process (Allen and Brown 1980). For this report $97 \% \mathrm{H}_{2} \mathrm{~S}$ control is assumed to be achievable for continuous process operation.

\section{Control Cost Factors}

Because of its upstream benefits, this process appears very attractive, both in terms of removal efficiency and the cost-effectiveness of control. Purchased equipment costs are influenced both by steam flow rates (which size the scrubbing units) and by $\mathrm{H}_{2} \mathrm{~S}$ mass flow rates (which influence the materials handling capacity requirement). Operating costs are also sensitive to $\mathrm{H}_{2} \mathrm{~S}$ flow rates.

When $\mathrm{H}_{2} \mathrm{~S}$ abatement costs were estimated using only the EIC process, solid-waste landfilling was found to cost more than either the injection or fertilizer reclamation options. This conclusion was reached following discussions with Mr. William Dyer of the EIC corporation in Newton, Massachusettes. Mr. Dyer reported that reclamation will have zero net costs to the firm because revenue from the sale of the $\left(\mathrm{NH}_{4}\right)_{2} \mathrm{SO}_{4}$, which is assumed to be reclaimed, will cover all reclamation and disposal costs. Specific parameter values for the equation appear in Appendix B. 


\section{DOWNSTREAM TREATMENT PROCESSES}

\section{Stretford Process}

\section{System Description}

The Stretford process is an offgas treatment system that may be used to scrub the noncondensible gas (NCG) stream passing through the NCG vent stack of geothermal power plants equipped with surface contact condensers. Figure 5.4 shows the Stretford unit in its typical placement in a flashedsteam system between the surface condensers and the cooling tower. Spent steam from the turbine is sent to the condensers, where noncondensible gases are vented to the Stretford unit for scrubbing. The condensate water is then routed to the cooling system before final disposal.

Surface condensers are expected to yield from 80 to $98 \%$ of the $\mathrm{H}_{2} \mathrm{~S}$ in the turbine exhaust steam to the Stretford unit, according to Larry Krumland of Pacific Gas and Electric. The rest of the $\mathrm{H}_{2} \mathrm{~S}$ will dissolve into the steam condensate and then be carried to the cooling tower for atmospheric release. Several variables, including $\mathrm{pH}$, temperature, pressure and total NCG content of the steam, are believed to determine the split between gaseous and aqueous $\mathrm{H}_{2} \mathrm{~S}$ emission pathways.

Figure 5.5 shows the noncondensible gas stream from the surface condensers being scrubbed with an aqueous solution containing sodium carbonate, sodium ammonium polyvanadate, and anthraquinone disulfonic acid (ADA) (Midwest Research Institute 1978). (a) The $\mathrm{H}_{2} \mathrm{~S}$ is oxidized in solution in the form of elemental sulfur prior to catalyst regeneration with air. Oxidized $\mathrm{H}_{2} \mathrm{~S}$ is skimed, centrifuged and then heated to form pure molten sulfur. The sulfur may either be removed as a waste product or may be reclaimed for sale as high purity sulfur. Parsons (1975) reports that reclaiming the sulfur appears to be the most cost-effective disposal option for the process at The Geysers, if a market can be found for the sulfur (EPA 1978) at a net of $\$ 25.00$ per metric ton (MT) in January 1980 dollars.

(a) At The Geysers sodium hydroxide ( $\mathrm{NaOH}$ ) is being substituted for sodium carbonate $\left(\mathrm{NA}_{2} \mathrm{CO}_{3}\right)$ in the treatment process. 


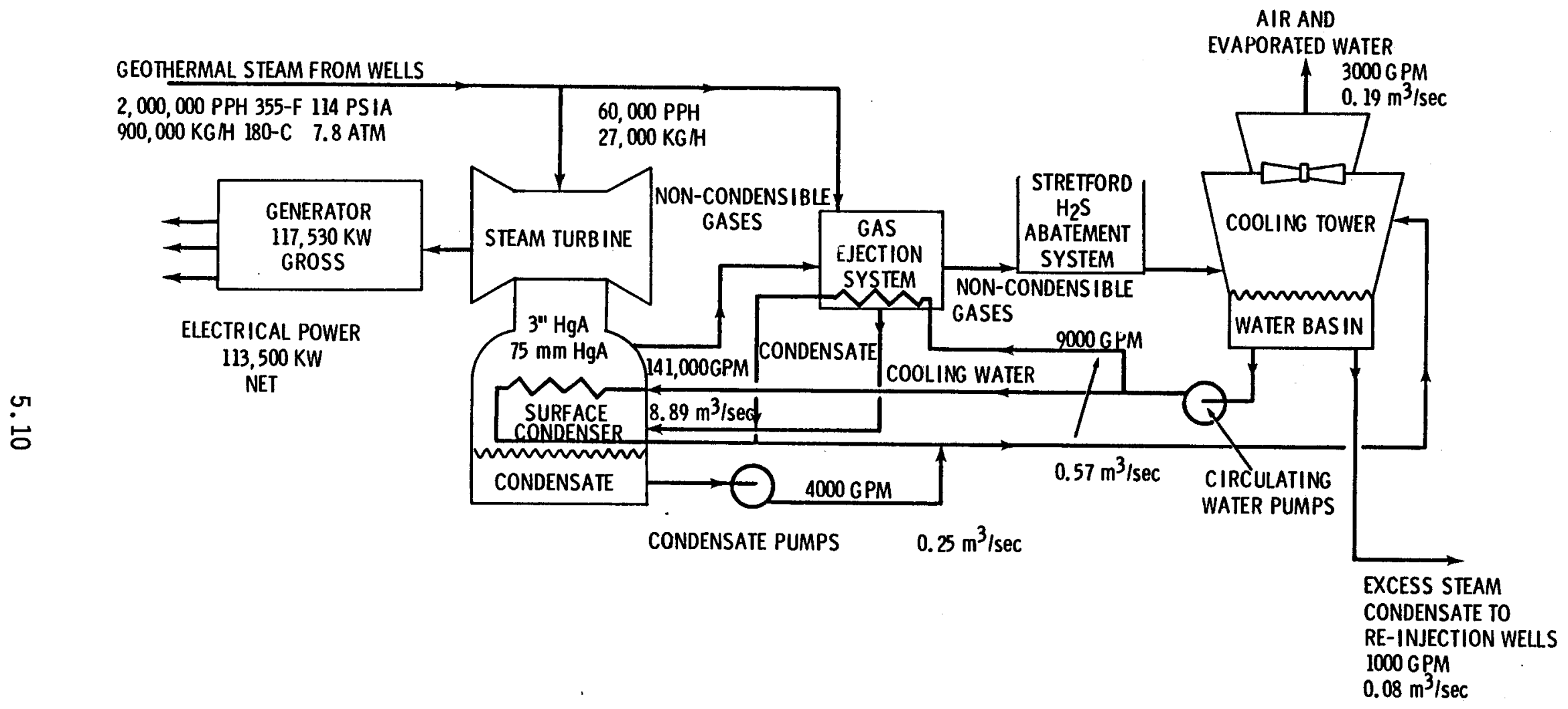

FIGURE 5.4. Modified System Cycle for Using Surface Condensers at The Geysers Power Plant (Laszlo 1976) 
CLEANED GAS

TO

COOLING TOWER

VENT GAS

FROM

POWER PLANT

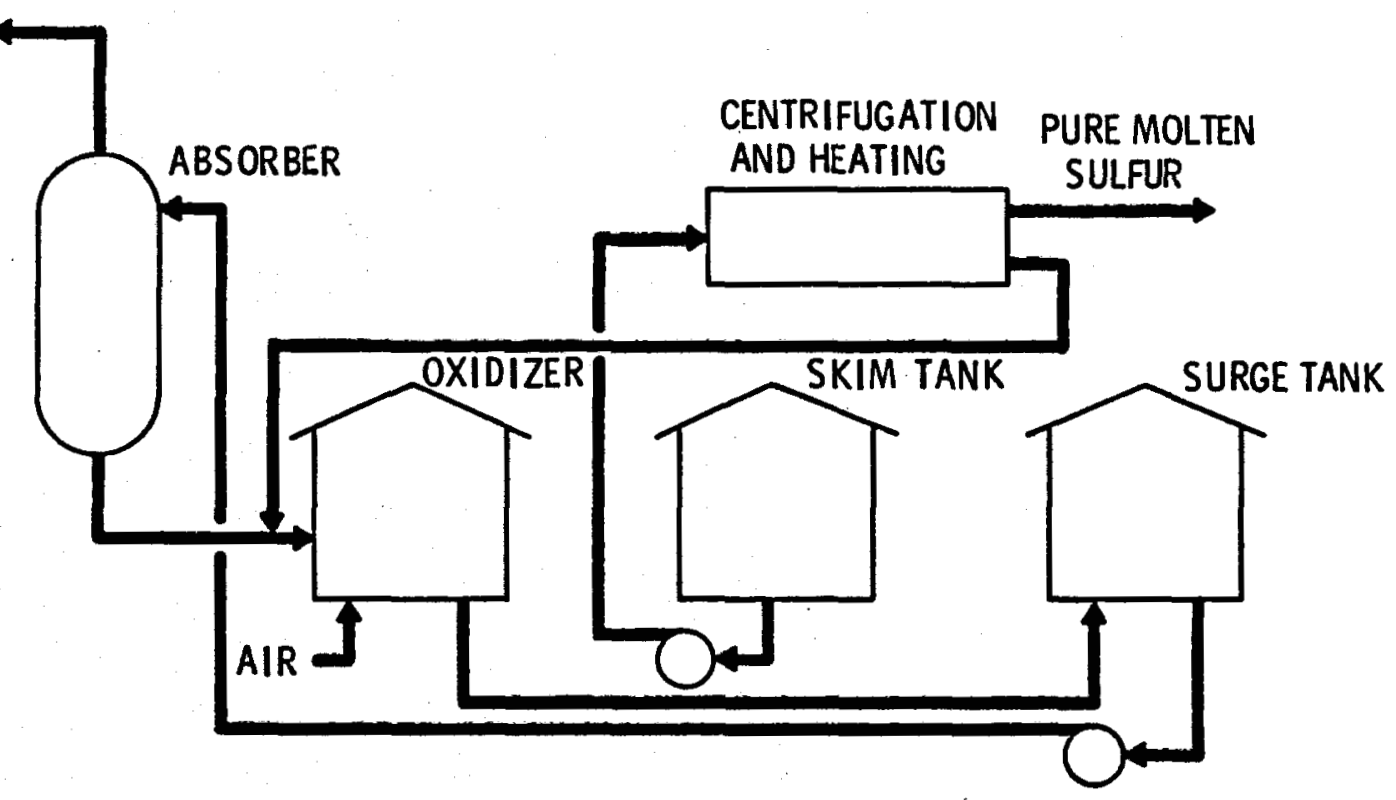

FIGURE 5.5. Typical Flow Diagram of Stretford Process at The Geysers (Laszlo 1976)

\section{Removal Efficiency}

The Stretford process has historically been used in industrial applications. Currently between 50 and 60 industrial units are successfully operating in the United States in various gas treating applications (Martin et al. 1978). Contractors will guarantee up to $99 \%$ removal efficiencies of the $\mathrm{H}_{2} \mathrm{~S}$ passing through this unit. In addition, the Stretford unit can tolerate and recover rapidly from $\mathrm{H}_{2} \mathrm{~S}$ over loads that may result from normal well variability (Martin et al. 1978). Larry Krumland of PG\&E reports that this characteristic was considered in selecting $\mathrm{H}_{2} \mathrm{~S}$ control technology for The Geysers. 
When the Stretford process is used with surface condensers, net emission control may be as low as $79 \%$ of total $\mathrm{H}_{2} \mathrm{~S}$ emissions $(0.99$ removal efficiency $\times 0.80$ condenser split), or as high as $99 \%$ under controlled conditions. Historically, direct contact condensers have been the type most commonly used in, or designed for, flashed-steam conversion systems. Compared to surface contact condensers the direct contact type exhibit higher heat transfer efficiencies and lower capital costs. Condenser selection will depend not only on reservoir temperature, but also on regulations and the relative prices of surface versus direct contact condensers.

\section{Control Cost Factors}

When the cost of employing surface condensers for the Stretford process is estimated only installation and use expenses (i.e., over and above direct contact condenser costs) are relevant. Purchased equipment costs for the Stretford process are driven not only by the incremental costs of surface condensers, but also by basic plant costs. Both costs are a function of $\mathrm{H}_{2} \mathrm{~S}$, noncondensible gas and fluid flow rates, which may or may not be known with sufficient accuracy prior to plant design to be used. $\mathrm{H}_{2} \mathrm{~S}$ mass flow, and to a greater extent total noncondensible gas flow, should be used to size a Stretford unit, but these data are not always precisely known prior to the design of a power plant. Therefore, they may not influence the plant's actual cost, but will instead influence operating costs after installation. Operating costs hinge on chemical usage, sulfur sales, and electricity required for process operation. The specific values of the parameters used in this report for estimation are found in Appendix B.

Sub-System Description: Hydrogen Peroxide

Although the Stretford process has a very high removal efficiency on the gas fraction delivered by surface condensers, it is unable to control cooling tower emissions. The process cannot control these emissions because surface condensers may allow from $2-20 \%$ of the gaseous $\mathrm{H}_{2} \mathrm{~S}$ in the flashed steam to dissolve into the steam that condenses inside the surface condensers of the 
cooling system. The condensate is then pumped to the cooling tower before it evaporates, is injected or returns to the condensers. Upon reaching the cooling tower, this $\mathrm{H}_{2} \mathrm{~S}$ may be emitted to the atmosphere. Figure 5.6 presents a simplified mass balance diagram of a steam driven geothermal generating unit found at The Geysers and fitted with a surface condenser and a Stretford plant. In that illustration, approximately $4 \%$ of the total $\mathrm{H}_{2} \mathrm{~S}$ loading in a raw fluid is shown to be escaping from the cooling towers through evaporation of the steam condensate. To abate such cooling tower $\mathrm{H}_{2} \mathrm{~S}$ emissions following Stretford treatment of the noncondensible gases, a system designed to use $\mathrm{H}_{2} \mathrm{O}_{2}$ to oxidize $\mathrm{H}_{2} \mathrm{~S}$ from the steam condensate has been investigated (White et al. 1977).

The peroxide process in theory converts most of the $\mathrm{H}_{2} \mathrm{~S}$ to elemental sulfur by combining the reactants in a 1:1 mole ratio (White et al. 1977). Using the condensate pump as a mixer, the $\mathrm{H}_{2} \mathrm{O}_{2}$ is added directly to the condensate line. The condensate transfer line itself may serve as a reactor and if additional retention time is required a holding tank may be constructed. Equipment required includes storage tanks for the $\mathrm{H}_{2} \mathrm{O}_{2}$, an injection metering pump to control the $\mathrm{H}_{2} \mathrm{O}_{2}$ addition rate, and (probably) a holding tank in the condensate transfer line. Because the sulfur must be removed from the condensate as it precipitates, a filtration system may be required. That system comprises most of the capital cost of the peroxide system. The peroxide system should be able to be fitted with relative ease into an existing geothermal plant that was not originally equipped for condensate treatment, so its incremental costs can be viewed as independent of the control costs for the Stretford plant that may be used in conjunction (White et al. 1977).

\section{Removal Efficiency}

The control level achieved depends on a fairly complex mix of condensate $\mathrm{H}_{2} \mathrm{~S}$ concentrations, temperature, mole ratios of reactants, and the presence of catalysts (such as PG\&E's iron catalyst). (White et al. 1977). Removal of $\mathrm{H}_{2} \mathrm{~S}$ from geothermal power plants when the Stretford and Peroxide systems are combined is expected to approach $99 \%$ under optimal operating conditions. 


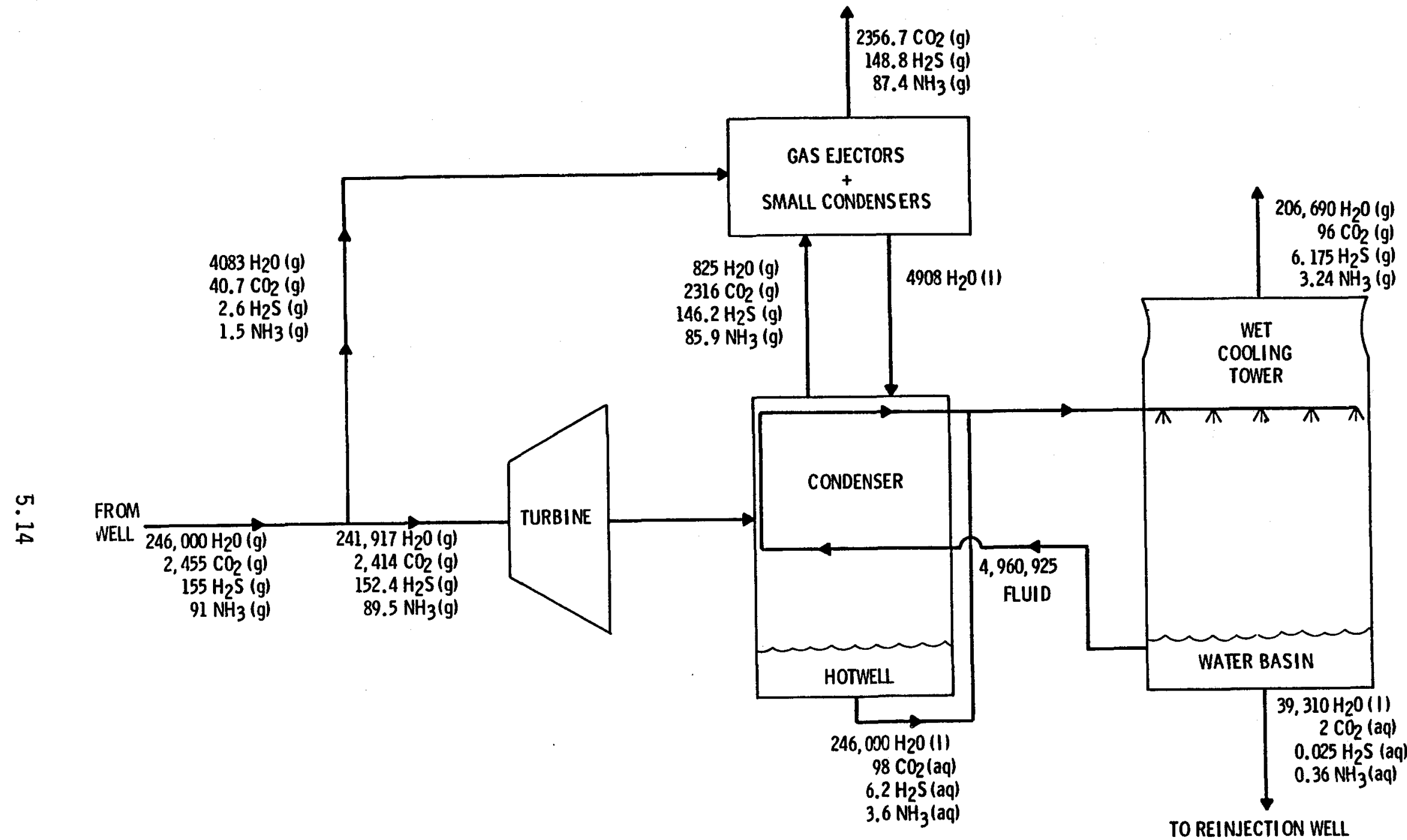

FIGURE 5.6. Mass Balance for 27 MWe Plant with Surface Condenser and Stretford Plant (Fairfax and McCluer 1972)

All flows are $\mathrm{kg} / \mathrm{hr}$. Entering $\mathrm{H}_{2} \mathrm{~S}$ concentration is $623 \mathrm{ppm}_{\mathrm{w}}$. Ninety-five percent $\mathrm{H}_{2} \mathrm{~S}$ control achieved with $1 \%$ of entering $\mathrm{H}_{2} \mathrm{~S}$ emitted from Stretford Plant and $4 \%$ from cooling tower.

TO REINJECTI ON WELL 


\section{Control Cost Factors}

Purchased equipment costs are expected to vary as a function of sulfur flow rates; however, no information on the impact of $\mathrm{H}_{2} \mathrm{~S}$ concentrations holding the steam flow rate constant is available. Operating expenses will be directly proportional to the quantity of $\mathrm{H}_{2} \mathrm{O}_{2}$ required for oxidizing the $\mathrm{H}_{2} \mathrm{~S}$ present in the steam condensate. As noted by Stanford Research Institute (SRI), the condenser $\mathrm{H}_{2} \mathrm{~S}$ split becomes a cost-determining factor at this point (White et. al. 1977). Estimates of specific parameters used for cost estimation in this report can be found in Appendix $B$.

\section{Iron Catalyst Process}

\section{System Description}

The natural $\mathrm{H}_{2} \mathrm{~S}$ oxidation that occurs in the cooling system of geothermal power plants can be increased by adding a metal catalyst. For use at The Geysers, Pacific Gas and Electric Company (PG\&E) has developed an iron catalyst system that has been permanently installed on Units $3,4,5,6$ and 11, according to Garratt Sharp of PG\&E. The system is also used intermittently on Units 2, 8, 9 and 10. In Figure 5.7 an iron catalyst is added to the circulating cooling waters to oxidize dissolved $\mathrm{H}_{2} \mathrm{~S}$ to elemental sulfur that first precipitates out as a sludge and is then filtered for removal. $\mathrm{H}_{2} \mathrm{~S}$ in the condensate from the direct contact condensers, as well as all the noncondensible gases captured by the condenser jet gas ejectors, is scrubbed by the system in the cooling tower. The system has several problems, including precipitation of sludges and increased corrosion. EPA (1978) has stated that corrosion problems are so severe that condenser life may be shortened from 30 years to only 7 years.

\section{Removal Efficiency}

Initially, PG\&E researchers hoped that the $90 \%$ efficiency the process exhibited during initial tests would be characteristic of the process. Garratt Sharp of PG\&E reports, however, that the process has been a disappointment in two respects. First, actual experience indicates that the process has an effective removal efficiency of on $1 y 50 \%$. The Iron Catalyst process was initially field-tested on Unit 1 , which has relatively low $\mathrm{H}_{2} \mathrm{~S}$ 


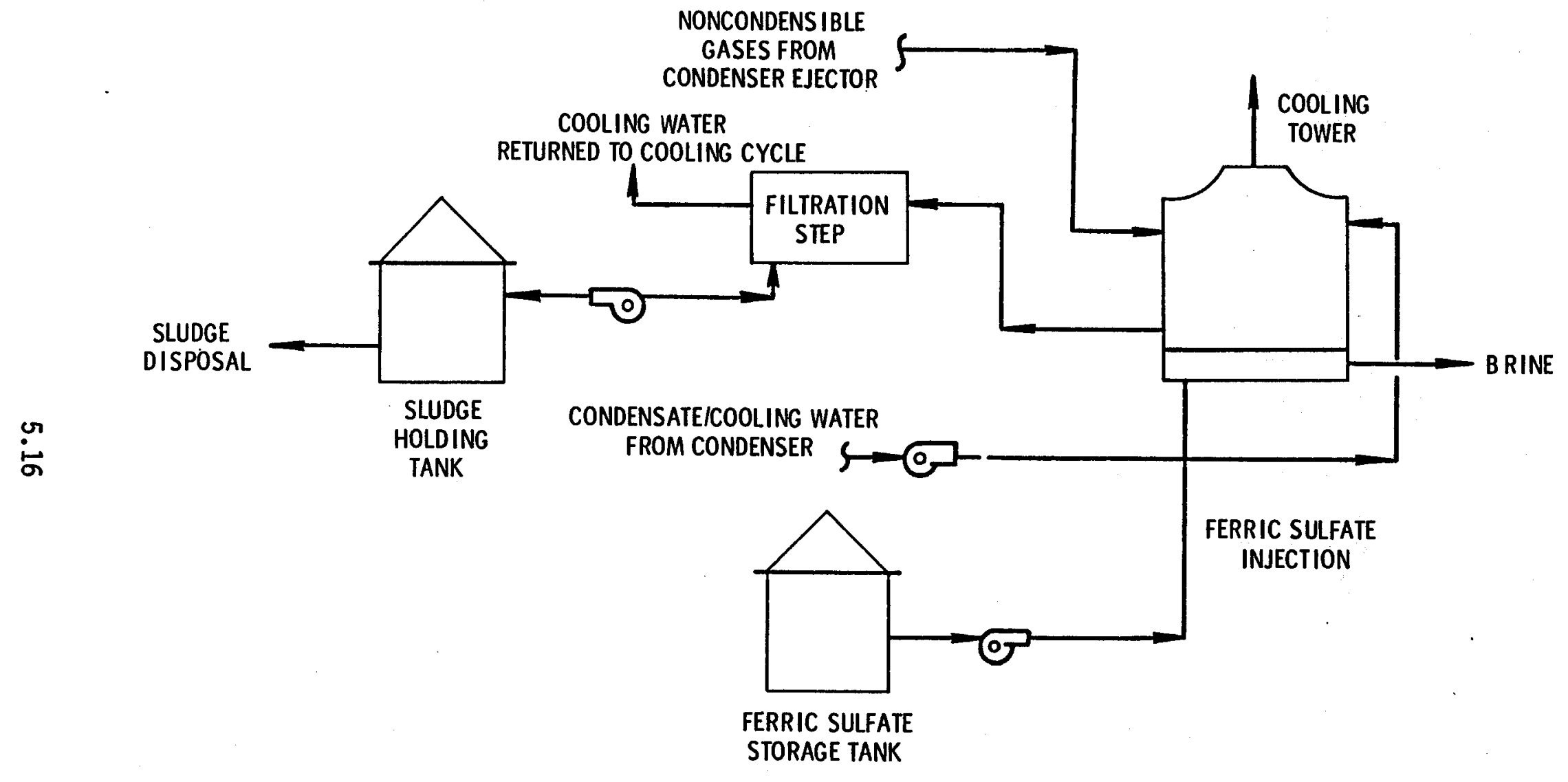

FIGURE 5.7. Iron Catalyst $\mathrm{H}_{2} \mathrm{~S}$ Removal Process (EPA 1978) 
content. Sufficient oxygen was available in the cooling tower to oxidize $90 \%$ of the $\mathrm{H}_{2} \mathrm{~S}$ that was present. However, when the control process was introduced to other production units that had significantly higher concentrations of $\mathrm{H}_{2} \mathrm{~S}$ in the raw steam at The Geysers, Mr. Sharp reports that the cooling towers were unable to adequately oxygenate the cooling waters to achieve anything more than approximately $50 \%$ control. Experiments are under way to use caustic soda and $\mathrm{H}_{2} \mathrm{O}_{2}$ to improve process removal efficiency.

Mechanical difficulties also affect the process' performance. Solids and sludges stick to the cooling tower nozzles and heat exchangers. Plugging is cormon and troublesome, and corrosion is still a problem.

Cleaning, maintenance and lost electric production are the biggest costs resulting from these two problem areas. Sludge disposal, which presents a problem, is currently being landfilled for final disposal.

\section{Control Cost Factors}

Purchased equipment costs for the Iron Catalyst (Ferrox, Ferrifloc, DryBox, etc.) process are primarily a function of the steam flow rate for a geothermal facility. In the literature operating costs are reported to be directly related to $\mathrm{H}_{2} \mathrm{~S}$ concentrations and the steam flow rates. Cooling tower cleaning, maintenance, and sludge disposal are all related to mass flows of $\mathrm{H}_{2} \mathrm{~S}$ and removal efficiencies. The specific values adopted for this report and used in cost estimations are found in Appendix B.

\section{COMPARATIVE PROCESS SUMMARY}

Processes have been developed to control $\mathrm{H}_{2} \mathrm{~S}$ emissions from geothermal power plants and have been field-tested with varying degrees of success. State-of-the-art control technology is probably best represented by the EIC and Stretford processes, which are being installed on generating units at The Geysers. The processes can achieve an overall level of $\mathrm{H}_{2} \mathrm{~S}$ control of up to $99 \%$.

Both the Iron Catalyst (downstream) and Dow (upstream) processes tentatively have been judged to be not as cost-effective as the Stretford process 
in achieving $\mathrm{H}_{2} \mathrm{~S}$ abatement. The Iron Catalyst process has both removal efficiency and solid waste disposal problems, while the Dow Peroxide process is very cost sensitive to both $\mathrm{H}_{2} \mathrm{~S}$ concentrations and brine flow rates.

Future state-of-the-art technology seems to center on application of the capital-intensive upstream EIC process. The process is relatively complex and requires a high degree of technical competence to design, install and operate effectively, but it has several advantages (EIC 1978; EPA 1978):

- provides clean steam to turbines, allowing optimal material selection for peak turbine efficiency

- abates $\mathrm{H}_{2} \mathrm{~S}$ emissions even during unit outages

- reduces boron and ammonia emissions along with $\mathrm{H}_{2} \mathrm{~S}$ emissions

- regenerates the process catalysts, thus minimizing chemical consumption and solid waste disposal problems

- achieves high levels of total removal efficiency--up to $99 \%$ of potential emissions.

Table 5.1 surmarizes the $\mathrm{H}_{2} \mathrm{~S}$ emission abatement processes reviewed here and tabulates the removal efficiencies and operating cost variables for each system. Cost estimates are presented in the case study that follows. 


\section{TABLE 5.1. $\mathrm{H}_{2} \mathrm{~S}$ Control Technology Sumary}

\begin{tabular}{|c|c|c|c|c|c|}
\hline Process & Application & Control Range & Inputs & Capital & Operating \\
\hline EIC & $\begin{array}{l}\text { Upstram - Steam } \\
\text { Ahead of Turbines }\end{array}$ & $95-99$ & $\begin{array}{l}\text { Regenerable } \\
\text { Copper } \\
\text { Catalyst }\end{array}$ & $\begin{array}{l}\text { Steam and } \\
\mathrm{H}_{2} \mathrm{~S} \text { Flow } \\
\text { Rates }\end{array}$ & $\begin{array}{l}\mathrm{H}_{2} \mathrm{~S} \text { Flow Rate, } \\
\text { Sludge or } \\
\text { Liquid Disposal }\end{array}$ \\
\hline Stretford & $\begin{array}{l}\text { Downstream - } \\
\text { Noncondensible } \\
\text { Gases }\end{array}$ & $80-98$ & $\begin{array}{l}\text { Regenerable } \\
\text { Catalysts }\end{array}$ & $\begin{array}{l}\mathrm{H}_{2} \mathrm{~S} \text { Flow } \\
\text { Rate }\end{array}$ & $\begin{array}{l}\mathrm{H}_{2} \mathrm{~S} \text { Flow Rate, } \\
\text { Sulfur Sales }\end{array}$ \\
\hline Peroxide & $\begin{array}{l}\text { Downstream - } \\
\text { Condensate Treat - } \\
\text { ment }\end{array}$ & $\begin{array}{l}\text { up to } \\
10.0\end{array}$ & $\begin{array}{l}\text { Chemical } \\
\text { Reagent }\end{array}$ & $\begin{array}{l}\text { Steam and } \\
\mathrm{H}_{2} \mathrm{~S} F \text { Flow } \\
\text { Rates }\end{array}$ & $\begin{array}{l}\mathrm{H}_{2} \mathrm{~S} \text { Flow Rate, } \\
\text { Sludge Disposal }\end{array}$ \\
\hline $\begin{array}{l}\text { Stretford } \\
\text { and } \\
\text { Peroxide }\end{array}$ & Downstream & $\begin{array}{l}\text { up to } \\
99.0\end{array}$ & Chemicals & $\begin{array}{l}\mathrm{H}_{2} \mathrm{~S} \text { Flow } \\
\text { Rate }\end{array}$ & $\begin{array}{l}\mathrm{H}_{2} \mathrm{~S} \text { Flow Rate, } \\
\text { Residual } \\
\text { Disposal }\end{array}$ \\
\hline Dow & $\begin{array}{l}\text { Upstream - Two } \\
\text { Phase Flow }\end{array}$ & $\begin{array}{l}\text { up to } \\
96.0\end{array}$ & $\begin{array}{l}\text { Chemical } \\
\text { Reagents }\end{array}$ & $\begin{array}{l}\mathrm{H}_{2} \mathrm{~S} \text { Flow } \\
\text { Rate, Fluid } \\
\text { Flow Rate }\end{array}$ & $\begin{array}{l}\mathrm{H}_{2} \mathrm{~S} \text { Flow Rate, } \\
\text { Sludge Diposal }\end{array}$ \\
\hline Iron Cata lyst & $\begin{array}{l}\text { Downstream - } \\
\text { Circulating } \\
\text { Cooling Waters }\end{array}$ & $\begin{array}{l}\text { up to } \\
50.0\end{array}$ & $\begin{array}{l}\text { Chemical } \\
\text { Reagents }\end{array}$ & $\begin{array}{l}\mathrm{H}_{2} \mathrm{~S} \text { Flow } \\
\text { FTow Rate }\end{array}$ & $\begin{array}{l}\mathrm{H}_{2} \mathrm{~S} \text { Flow Rate } \\
\text { Sludge Removal }\end{array}$ \\
\hline & Peroxide Addition & up to & $\begin{array}{l}\text { Chemical } \\
90.0\end{array}$ & $\begin{array}{l}\mathrm{H}_{2} \mathrm{~S} \text { Flow } \\
\text { Reagents }\end{array}$ & $\begin{array}{l}\mathrm{H}_{2} \mathrm{~S} \text { Flow Rate } \\
\text { Rate }\end{array}$ \\
\hline
\end{tabular}




\subsection{CASE STUDY}

A site specific investigation of the costs of $\mathrm{H}_{2} \mathrm{~S}$ emission control is presented in this section. Site selection criteria are presented first, followed by a description of the chosen site and estimates of abatement costs.

\section{SITE SELECTION CRITERIA}

A site chosen for evaluating the costs of meeting environmental standards should exhibit several characteristics:

- The site should have significant development potential for energy recovery and utilization.

- The resource should be known to contain the emissions under study to enable development of reliable control cost estimates.

- Commercial interest in the site should exist.

Many resources meeting the above criteria exist in the western United States. The resource chosen for cost estimation in this report was the Valles Caldera KGRA in New Mexico. The site represents approximately 13\% of the potential electrical generation capacity that may be obtainable from liquiddominated, high-temperature, hydrothermal convection systems (2700 MWe of 21,000 MWe for 30 years) (Brook et al. 1978).

Two developers have entered a joint venture at the site, which is located on the Baca Ranch. Resource exploitation will be performed by Union 0il Company, while the Public Service Company of New Mexico will handle power distribution. A 50 MWe flashed-steam plant has been selected as the most cost-effective energy conversion facility for the site. Power is expected to be on line in 1982 (Energy User News July 17, 1978). Injection has been selected for liquid-waste disposal. The resource has a total dissolved solids concentration of $7500 \mathrm{ppm}_{\mathrm{W}}$, with a $\mathrm{H}_{2} \mathrm{~S}$ concentration ranging from 290 to well over $500 \mathrm{ppm}_{W}$ in the raw steam, as noted in Appendix $A$. The site's subsurface temperature has been estimated at $273^{\circ} \mathrm{C}$ (Brook et al. 1978). 
The site appears to be a satisfactory choice for investigating $\mathrm{H}_{2} \mathrm{~S}$ emission control costs, based on several factors: 1) the commercial interest in the site; 2) its larger-than-average estimated energy potential; 3) its relatively high $\mathrm{H}_{2} \mathrm{~S}$ loading; 4) its demonstrated ability to produce the 1 arge volume flows necessary for power production; and 5) the region's ability to accept injected fluids. Table 6.1 sumarizes the pertinent KGRA data for the Baca Ranch.

\title{
TABLE 6.1. Baca, New Mexico Resource Description
}

\author{
Site: Valles Caldera KGRA, New Mexico \\ Temperature: $273^{\circ} \mathrm{C}$ \\ Hydrogen Sulfide Concentration: 290 to $550 \mathrm{ppm}_{\mathrm{w}}$ in the raw steam \\ Expected Well Flow Rate (Assumed): $500,000 \mathrm{lb} / \mathrm{hr}$ per well \\ Total Dissolved Solids Concentration: 7,500 ppm \\ Liquid Waste Disposal: Injection
}

Because the TDS content is relatively moderate, injection should be practiced with minimal, if any, liquid-waste pretreatment. The site's relatively high $\mathrm{H}_{2} \mathrm{~S}$ concentration is expected to require a high degree of abatement to prevent significant deterioration of ambient air quality in this recreational region (Roberts 1976 ).

\section{COST ESTIMATION}

Emission control costs at the Baca site were estimated from the cost functions in Appendix B. Power generation costs and steam flow rates were derived from the PNL GEOCOST model. All assumptions regarding reservoir parameters used to model the Baca site for this case study are given in the summary of the GEOCOST mode1 (Bloomster 1975). Injection expenses for disposal of spent fluids have been included in the power generation cost estimates, which are expressed in January 1980 dollars. 
$\underline{H}_{2}$ S Abatement Costs

With the Stretford and EIC processes, varying the fraction of the $\mathrm{H}_{2} \mathrm{~S}$ laden fluid being scrubbed was assumed to achieve the control level shown on the horizontal axis in Figure 6.1. The relation is given as:

Percentage Control Achieved $=$ Fluid Fraction Scrubbed $\times$ Removal Efficiency.

Producers are assumed to achieve only the minimum abatement level required to comply with effluent limitations, un less incentives exist to achieve higher levels. One such incentive may be a reduction in the damage that corrosive $\mathrm{H}_{2} \mathrm{~S}$ can cause. By using upstream treatment processes, such benefits may be realized. The value of such potential benefits was not estimated in this study, however.

Only EIC, Stretford and peroxide condensate treatment process cost estimates are presented here. The iron oxide process has been found to be both inefficient and very costly and the Dow process is simply too costly to be practical. The Stretford and EIC processes represent the most cost-effective systems available.

Although calculating the expected abatement level that a process will achieve for a given set of conditions is relatively simple, accurately estimating the percentage control required for a given site to meet an ambient standard (e.g., $30 \mathrm{ppb}_{w}$ ) is much more difficult. The minimum level of emission control that will be sufficient to achieve compliance with any given ambient air quality standards at the Baca site, or at any other KGRA, is not known precisely.

Figure 6.1 presents $\mathrm{H}_{2} \mathrm{~S}$ abatement costs for each of the individual processes at the Baca site. The costs were developed from the cost estimates in Table C.1 of Appendix C.

Abatement costs were estimated using an assumed $\mathrm{H}_{2} \mathrm{~S}$ concentration of $250 \mathrm{ppm}_{\mathrm{w}}$ in the raw flashed steam. Using this concentration provides a conservative estimate of the minimum abatement costs most likely to be encountered 


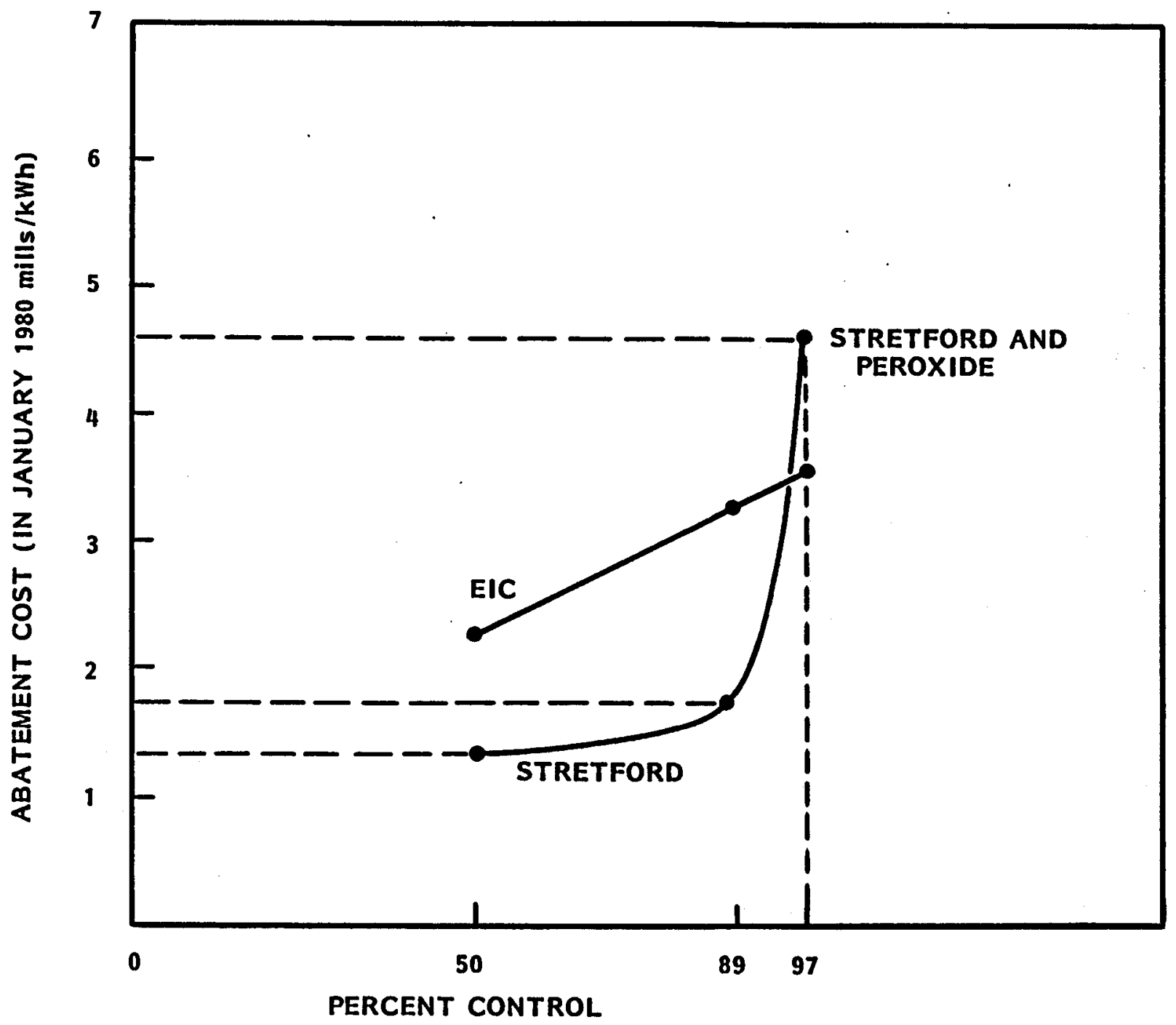

FIGURE 6.1. Comparative $\mathrm{H}_{2} \mathrm{~S}$ Abatement Costs for Baca, New Mexico (Appendix C, Table C.1) (a)

(a) $250 \mathrm{ppm}_{\mathrm{W}} \mathrm{H}_{2} \mathrm{~S}, 110$ We plant, $273^{\circ} \mathrm{C}$ downhole, $2,400,090$ lb of steam $/ \mathrm{hr}$ 
at the site, since measured concentrations average $290 \mathrm{ppm}_{\mathrm{w}}$ and have been known to exceed $500 \mathrm{ppm}_{\mathrm{w}}$. The $97 \%$ abatement level represents the state-ofthe-art limits in $\mathrm{H}_{2} \mathrm{~S}$ emissions control. Higher abatement levels can only be achieved by adding additional units of the same processes in series. The costs of redundant scrubbing systems are virtually identical to the costs of the first treatment units in a series because the replicated units in the processes evaluated in this report are so heavily capital-intensive. Capital costs are more sensitive to steam flow rates and volumes of fluids handled than to $\mathrm{H}_{2} \mathrm{~S}$ concentrations.

At control levels of $97 \%$, Figure 6.1 indicates that the StretfordPeroxide combination treatment system will most likely increase power production costs by approximately 4.6 mills per $\mathrm{kWh}$. The EIC process is less expensive for high levels of $\mathrm{H}_{2} \mathrm{~S}$ control, probably for all levels in excess of $90 \%$ control. The Stretford system is most cost effective up to the $89 \%$ control level.

In terms of net present value, the cost of achieving $97 \%$ emission control over the project's 30-year expected economic life is approximately $\$ 39,300,000$, based on a real (inflation free) discount rate of $5 \%$. This is $\$ 19,610,000$ greater than the net present value of the cost of achieving $89 \%$ emission control. To achieve economic and regulatory efficiency, the environmental benefits gained by the higher level of control must be worth at least the incremental cost of control $(\$ 19,610,000)$.

If the value of the benefits of preventing the additional odor nuisance (caused by allowing $89 \%$ control instead of requiring $97 \%$ control) do not equal or exceed the costs of preventing the extra nuisance, then clearly the regulations should not require $97 \%$ abatement. Empirical investigations are required to establish whether the maximum technically feasible abatement level (97\%) is also the socially optimal level of environmental protection.

\section{CASE STUDY SUMMARY}

Baca, New Mexico, was selected as an appropriate geothermal site for a case study of the cost of $\mathrm{H}_{2} \mathrm{~S}$ abatement. The resource, undergoing commercial 
development, has an $\mathrm{H}_{2} \mathrm{~S}$ concentration greater than $290 \mathrm{ppm}_{\mathrm{w}}$ in the raw steam and will be subject to emission regulations. To meet a 97\% abatement standard, abatement costs for a flashed steam facility were found to increase total power costs by $3.55 \mathrm{mills}$ per $\mathrm{kWh}$, a minimum estimate for this standard because it is based on the assumption that $\mathrm{H}_{2} \mathrm{~S}$ concentrations will average $250 \mathrm{ppm}_{\mathrm{w}}$ in the raw steam. 


\section{REFERENCES}

Aerospace Corporation. 1976. Geothermal Energy, an Environmental and Safety Mini-0verview Survey. Prepared for Environment and Safety, Energy Research and Development Administration, Germantown, Maryland.

Air Resources Board, State of California. 1978. Consideration of Model Control Strategy for Hydrogen Sulfide Emissions at the Geysers. Sacramento, California.

Allen, G. W. and F. C. Brown. 1980. Highlights of the Test Results from the Operation of a $5 \mathrm{MW}$ Pilot Plant Demonstration of the EIC Process at the Geysers. EIC Corporation, Newton, Massachusetts.

Axtman, R. C. 1975. "Environmental Impact of a Geothermal Power Plant." Science, $187(4179)$.

Barnes, I. et a1. 1973. Chemical Composition of Naturally Occurring Fluids in Relation to Mercury Deposits in Part of North Central California. USGS, Mento Park, California.

Barnes, I. and J. D. Hem. 1973. Chemistry of Subsurface Waters. USGS, Men lo Park, California.

Bloomster, C. H. 1975. Economic Analysis of Geothermal Energy Costs. BNWL-SA-5596, Pacific Northwest Laboratory, Richland, Washington.

Bowen, R. G. 1973. "Environmental Impact of Geothermal Energy Development." In Geothermal Energy, eds. P. Kruger and C. Otte, Stanford University Press, Stanford, California.

Brook, C. A. et a 1. 1978. "Hydrothermal Convection Systems with Reservoir Temperature $900 \mathrm{C} . "$ In Assessment of Geothermal Resources of the United States-1978, Geological Circular 790, ed. L. P. Muffler, U.S. Department of the Interior, Geological Survey, Washington, D.C.

Cosner, S. P. 1977. The L.B.L. Geothermal Fluid Data File. Lawrence-Berkeley Laboratory, University of California, Berketey, California.

Defferding, L. J. et al. 1978. Geothermal Liquid Waste Disposal - State-of the-Art Review. BNWL-2404, Pacific Northwest Laboratory, Richland, Washington.

Doane, J. W. et a1. 1976. The Cost of Energy from Utility-Owned Solar Electric Systems. A Required Revenue Methodology for ERDA/EPRI Evaluations. Jet Proputsion Laboratory, JPL 5040-29, California Institute of Technology, Pasadena, California.

EIC Corporation. 1976. Control of Hydrogen Sulfide Emission from Geothermal Power Plants. Newton, Massachusetts. 
EIC Corporation. 1978. Control of Hydrogen Sulfide Emission from Geothermal Power Plants. Final report on Task C.6, Optimization and Economic Studies, EIC Corporation, Newton, Massachusetts.

"Energy User News." July 17, 1978.

Environmental Protection Agency. 1978. Survey of Environmental Regulations Applying to Geothermal Exploration, Development and Use. Interagency Energy - Environment Research and Deve lopment Program Report. EPA-600/7-78-014. United States Environmental Protection Agency, Office of Research and Development, Industrial Environmental Research Laboratory, Cincinnatti, Ohio.

Futures Group. 1975. A Technology Assessment of Geothermal Energy Resource Deve lopment. Prepared for National Science Foundation by Futures Group, Glastonbury, Connecticut.

Lasz10, J. 1976. Application of the Stretford Process for $\mathrm{H}_{2} \mathrm{~S}$ Abatement at The Geysers Geothermal Power Plant. Pacific Gas and Electric Company, San Francisco, California.

Mariner, R. H. et al. 1974a. The Chemical Composition and Estimated Minimum Thermal Reservoir Temperatures of Selected Hot Springs in Oregon. USGS, Men lo Park, California.

Mariner, R. H. et al. 1974b. The Chemical Composition and Estimated Minimum Thermal Reservoir Temperatures of the Principal Hot Springs of Northern and Central Nevada. USGS, Menlo Park, California.

Mariner, R. H. et al. 1975. The Minor and Trace Elements, Gas, and Isotope Compositions of the Principal Hot Springs of Nevada and Oregon. USGS, Menlo Park, California.

Mariner, R. H., T. S. Presser and W. C. Evans. 1976. Chemical Data for Eight Springs in Northwestern Nevada. USGS, Menlo Park, California.

Mariner, R. H., T. S. Presser and W. C. Evans. 1977. Hot Springs of the Central Sierra Nevada, California. USGS, Menlo Park, California.

Martin, J. B. et al. 1978. Environmental, Safety, and Health Standards Identification for Geothermal Energy: Report 1: Airborne Emissions. PNL-2581, Pacific Northwest Laboratory, Richland, Washington.

Midwest Research Institute. 1978. Evaluation of $\mathrm{H}_{2} \mathrm{~S}$ Control Technology for Geothermal Energy Sources. Prepared for Department of Energy, Division of Environmental Control Technology by Midwest Research Institute, Kansas City, Missouri. 
Nathenson, M. and L. J. P. Muffler. 1976. "Geothermal Resources in Hydrothermal Convection Systems and Conduction Dominated Areas." In Assessment of Geothermal Resources of the United States - 1975, Third printing of Geological Survey Circular 726, eds. E. E. White and D. L. Williams, U.S. Department of the Interior, Geologic Survey, Washington, D.C.

Pacific Gas and Electric Company. 1977. "Demonstration of EIC Copper Sulfate Process for Removal of Hydrogen Sulfide and Other Trace Contaminants from Geothermal Steam at Turbine Inlet Temperatures and Pressures." Proposal to the United States Energy Research and Development Administration, Pacific Gas and Electric Company, San Francisco.

Parsons Company, The Ralph M. 1971. "Hydrogen Sulfide Abatement Facilities for Geothermal Power Production Facilities, The Geyers, California." Comparative Process Study for Pacific Gas and Electric Company, by The Ralph M. Parsons Company, Pasadena, California.

Pigford, T. H. et al. 1975. "Fuel Cycles for Electrical Power Generation." In Comprehensive Standards: The Power Generation Cases, EPA 68-01-0561, prepared for U.S. Environmental Protection Agency, by Teknekron, Inc, Washington, DC.

Presser, T. S., and I. Barnes. 1974. Special Techniques for Determining Chemical Properties of Geothermal Water. USGS Water - Resources Investigations 22-74, Menlo Park, California.

Roberts, V. W. 1976. "Energy Conversion and Economics for Geothermal Power Generation at Heber, California, Valles Caldera, New Mexico, and Raft River, Idaho-Case Studies." Topical Report 2, EPRI-ER-301, Electrical Power Research Institute, PaTo ATto, California.

Shannon, D. W. 1978. Brine Chemistry and Combined Heat/Mass Transfer. EPRI ER-635, Electric Power Research Institute, Palo Alto, California.

She 110 il Company. 1978. Shareholder News, Preview of 1977 Annual Report. She11 0il Company, Houston, Texas.

Sung, R. et a 1. 1977. Preliminary Cost Estimates of Pollution Control Technologies for Geothermal Developments. TRW Environmental Engineering Division, Redondo Beach, California.

Swanberg, C. A. (undated). "Physical Aspects of Pollution Related to Geothermal Energy Development." New Mexico State University, Las Cruces, New Mexico.

Swanson, J. R. 1977. GEOTHERM Data File. USGS, Reston, Virginia.

U.S. Environmental Protection Agency (EPA). 1977. Western Energy Resources and the Environment: Geothermal Energy. EPA-600/9-77-010. U.S. Environmental Protection Agency, Washington, D.C. 
U.S. Environmental Protection Agency. 1978. Pollution Control Guidance for Geothermal Energy Development. Office of Energy, Minerals and Industry, Cincinnatti, Ohio.

White, R. K. et al. 1977. Environmental Analysis for Geothermal Energy

Development in the Geyers Region. Volumes I and III. Prepared for State of California Energy Comission, by Stanford Research Institute, Menlo Park, California.

Willey, L. M., J. R. O'Neil and J. B. Rapp. 1974. Chemistry of Thermal Waters in Long Valley, Mono County, California. USGS, Menlo Park, California. 


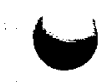

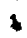

APPENDIX A

RESERVOIR GEOCHEMISTRY SUMMARY 
APPENDIX A

\section{RESERVOIR GEOCHEMISTRY SUMMARY}

\section{TABLE A.1. Reservoir Geochemistry Surmary}

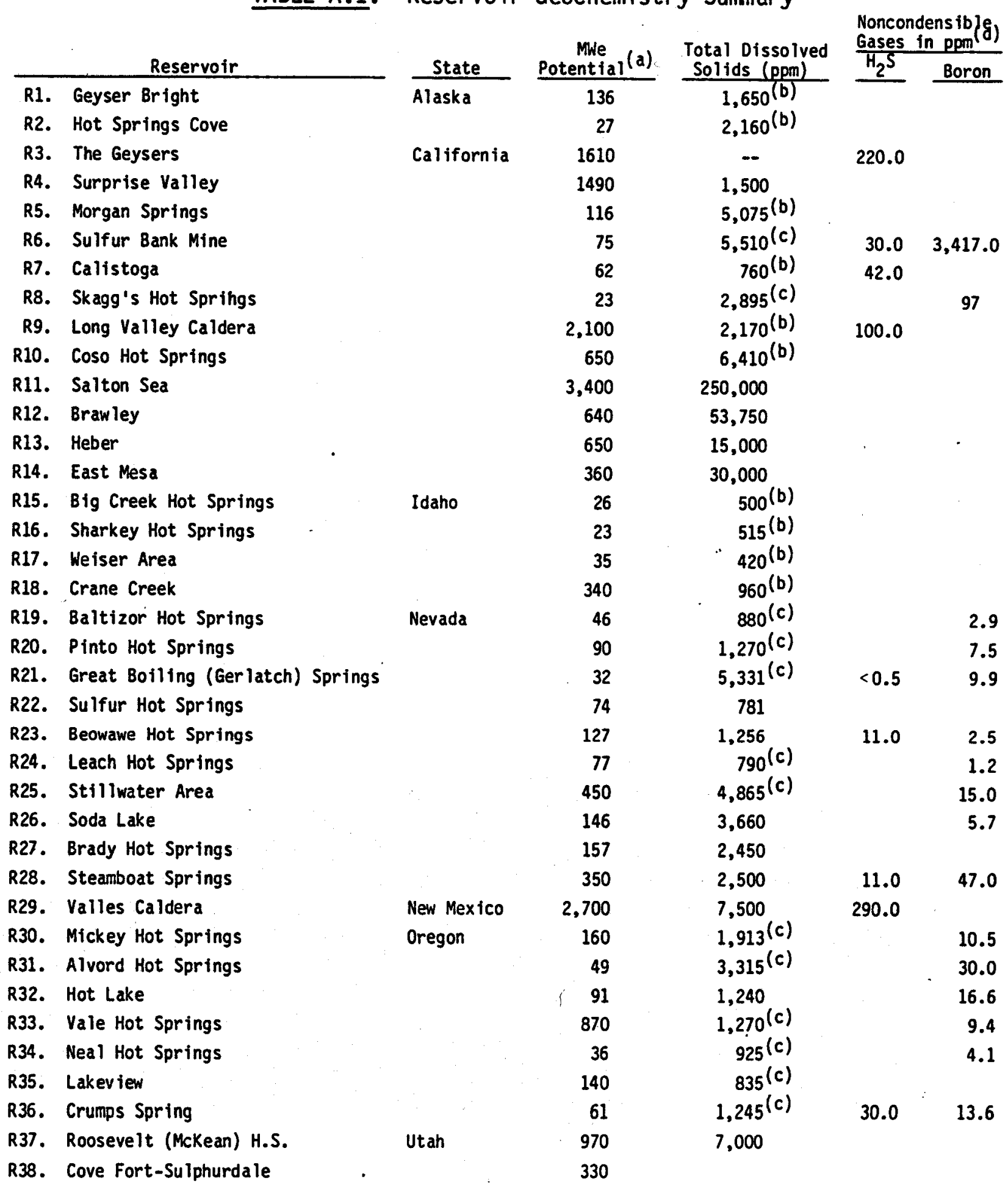

TOTAL

18,719 


\section{TABLE A.1. Reservoir Geochemistry Summary (contd)}

\begin{tabular}{|c|c|c|c|c|c|c|c|c|c|}
\hline \multirow{2}{*}{\multicolumn{2}{|c|}{ Reservoir }} & \multicolumn{2}{|c|}{$\begin{array}{l}\text { Soluble Heavy } \\
\text { Metals ppm }\end{array}$} & \multirow{2}{*}{$\begin{array}{c}\text { Temperature } \\
\text { (Subsurface) } \\
{ }_{0} \mathrm{C} \\
\end{array}$} & \multicolumn{4}{|c|}{ Constituents } & \multirow{2}{*}{$\begin{array}{l}\text { Spec. } \\
\text { Cond. }\end{array}$} \\
\hline & & Hg (Vapors) & AS & & $\overline{\mathrm{S}_{i} \mathrm{O}_{2}}$ & $\mathrm{Na}$ & $\mathrm{Cl}$ & $\mathrm{pH}$ & \\
\hline R1. & Geyser Bight & & & 208 & 303 & 441 & 569 & 7.5 & \\
\hline R2. & Hot Springs Cove & & & 164 & 88 & 603 & 1,126 & 5.9 & \\
\hline R3. & The Geysers & $(.02)$ & $(.05)$ & 237 & & & & & \\
\hline R4. & Surprise Valley & & & 152 & 200 & 343 & 223 & 8.91 & \\
\hline R5. & Morgan Springs & & & 217 & 233 & 1,398 & 2,430 & - & \\
\hline R6. & Sulfur Bank Mine & 1.5 & & 194 & 203 & 1,723 & 900 & 2.7 & 7,880 \\
\hline R7. & Calistoga & & & 144 & 139 & 212 & 255 & 9.0 & \\
\hline R8. & Skagg's Hot Springs & $.98 \mu \mathrm{g} / \mathrm{l}$ & & 113 & 124 & 945 & 54 & 7.2 & 3,690 \\
\hline R9. & Long Valley Caldera & $.10 \mu g / 2$ & $2.2 \mathrm{mg}$ & 227 & 340 & 552 & 842 & 9.2 & 1,920 \\
\hline R10. & Coso Hot Springs & & & 220 & 458 & 1,630 & 3,040 & 8.5 & \\
\hline R11. & Salton Sea & & & 323 & 316 & 10,800 & 15,300 & 8.11 & \\
\hline R12. & Braw ley & & & 253 & & & & & \\
\hline R13 & Heber & & & 175 & &. & & & \\
\hline R14 & East Mesa & & & 182 & & & & & \\
\hline R15. & Big Creek Hot Springs & . & & 162 & 150 & 220 & 29 & 7.5 & \\
\hline R16. & Sharkey Hot Springs & & & 114 & 91 & 270 & 51 & 7.4 & \\
\hline R17. & Weiser Area & & & . 130 & 140 & 140 & 56 & 9.3 & \\
\hline R18. & Crane Creek & & & 171 & 180 & 290 & 300 & 7.1 & \\
\hline R19. & Baltizor Hot Springs & .001 & .07 & 158 & 160 & 180 & 48 & 8.0 & 947 \\
\hline R20. & Pinto Hot Springs & .004 & .08 & 173 & 150 & 330 & 160 & 7.1 & \\
\hline \multirow[t]{2}{*}{ R21. } & Great Boiling & & & & & & & & \\
\hline & (Gerlatch) Springs & & & 178 & 172 & 1,460 & 2,200 & 7.62 & 6,350 \\
\hline R22. & Sulfur Hot Springs & .0015 & & 178 & 75 & 103 & 0 & 7.8 & 652 \\
\hline R23. & Beowawe Hot Springs & .0017 & .05 & 229 & 534 & 257 & 70 & 9.8 & 1,490 \\
\hline R24. & Leach Hot Springs & .0006 & $<.01$ & 162 & 198 & 193 & 33 & 8.8 & 811 \\
\hline R25. & Stillwater Area & & & 159 & 170 & 1,480 & 2,200 & 7.57 & 6,910 \\
\hline R26. & Soda Lake & & & 157 & 160 & 1,000 & 1,500 & 7.90 & 5,110 \\
\hline R27. & Brady Hot Springs & & & 155 & 279 & 774 & 968 & 7.3 & \\
\hline R28. & Steamboat Springs & & & 200 & 353 & 2,047 & 1,345 & 9.3 & 3.34 \\
\hline OR29. & Valles Caldera & & & 273 & & & & & \\
\hline R30. & Mickey Hot Springs & .0001 & .01 & 205 & 200 & 550 & 240 & 8.05 & \\
\hline R31. & Alvord Hot Springs & .0001 & .04 & 181 & 184 & 960 & 780 & 8.1 & \\
\hline R32. & Hot Lake & .0004 & .01 & 191 & 190 & 500 & 300 & 9.21 & 688 \\
\hline R33. & Vale Hot Springs & & & 157 & 130 & 310 & 360 & 7.47 & 1,530 \\
\hline R34. & Neal Hot Springs & .0001 & .02 & 188 & 180 & 190 & 120 & 7.32 & 1,010 \\
\hline R35. & Lakeview & & & 150 & 146 & 280 & 170 & 8.4 & \\
\hline R36. & Crumps Spring & .0004 & .46 & 167 & 180 & 293 & 263 & 8.7 & 1,490 \\
\hline R37. & Roosevelt (McKean) H.S. & & & 265 & 313 & 2,500 & 4,240 & & \\
\hline R38. & Cove Fort-Sulphurdale & & & 167 & & & & & \\
\hline
\end{tabular}

(a) Me Potential = Megawatts of electrical generating potential for 30 years as determined by USGS (Brook et al.).

(b) Approximation of TDS $=\left(\mathrm{S}_{\mathrm{i}} \mathrm{O}_{2}+\mathrm{Na}+\mathrm{C} 1\right) \times 1.25$.

(c) Estimated linearly from $\operatorname{TDS}^{2}=250+0.57 \times$ (Specific Conductance), where 250 roughly corresponds to the spec if ic conductance of water and 0.67 indicates the ions are $50 \%$ monovalent (such as $\mathrm{Na}^{+}$and $\mathrm{Cl}^{-}$) and $50 \%$ divalent (from silicates). Over estimation is expected for a few resources, hut generally the results are retained as lower range TDS predictions.

(d) Parts per million in the raw steam by weight.

$$
\text { A. } 2
$$




\section{APPENDIX B}

HYDROGEN SULFIDE CONTROL COST FUNCTIONS 
APPENDIX B

\section{HYDROGEN SULFIDE CONTROL COST FUNCTIONS}

\section{CONTROL COSTS - DOW PROCESS}

Initial estimates indicate that the Dow Process will probably be the most expensive of the four primary $\mathrm{H}_{2} \mathrm{~S}$ treatment processes considered to be technically feasible. A discussion of control costs is broken into capital and operating cost components in the following sections.

\section{Purchased Equipment}

Preliminary cost estimates of the oxygenation process developed by the Dow Chemical Company have been reviewed and evaluated by numerous authors in the literature (EPA 1978; Midwest Research Institute 1978; Sung, et al. 1977). Based on these reviews and on information provided to PNL by John Wilson and Bob Southard of the Dow Chemical Company, a purchased equipment cost function has been developed below.

The equipment required for the packed column design includes the packed tower, the oxidant supply system, instrumentation, piping, and flow meters. Costs are expected to vary exponentially with changes in brine flow rates, independent of $\mathrm{H}_{2} \mathrm{~S}$ concentrations.

\section{Operating Costs}

Operating costs are sensitive to $\mathrm{H}_{2} \mathrm{~S}$ flow rates. Mass balance calculations indicate a residual solid waste may be generated as a result of this process, requiring disposal (EPA 1978). For each mole of $\mathrm{H}_{2} \mathrm{~S}$ oxidized, one mole of elemental sulfur is assumed to be generated and require disposal. Disposal is assumed to be achieved by solid-waste landfilling a $\$ 25.00$ per ton in 1980 dollars (EPA 1978). Electricity requirements are assumed to be independent of the $\mathrm{H}_{2} \mathrm{O}_{2}$ use rate. 
EQUATION B.1. Dow Process Cost Functions

$$
\begin{aligned}
\mathrm{PE}_{1980} & =\mathrm{IB} \times(\mathrm{BA} / \mathrm{BB})^{\mathrm{X}}+(\mathrm{NT} / \mathrm{WF} \times \mathrm{BA} \times \mathrm{TC}) \\
\mathrm{AOC}_{1980} & =\left(\mathrm{PH} \mathrm{H}_{2} \mathrm{~S} \times \mathrm{CF}\right) \times[(\mathrm{MR} \times \mathrm{MW} 1 \times \mathrm{MW} 2 \times \mathrm{PC} \times \mathrm{SR})+(\mathrm{C} 1 \times \mathrm{SRE} \times \mathrm{C} 2 \times \mathrm{DC})]
\end{aligned}
$$

Variables:

$$
\begin{aligned}
& { }^{A O C} C_{1980}=\text { Annual Operating Cost in January } 1980 \text { dollars } \\
& B A=\text { Brine Flow Rate in the Proposed Facility (1b/hr) } \\
& B B=\text { Brine Flow Rate in the Design Facility }\left(5 \times 10^{6} \mathrm{lb} / \mathrm{hr}\right) \\
& \mathrm{Cl}=\text { Constant }\left(32 \mathrm{lb} \mathrm{S} / 34 \quad \mathrm{lb} \mathrm{H} \mathrm{H}_{2} \mathrm{~S}\right) \\
& \text { C2 }=\text { Constant (1 Metric Ton S/2205 lb S) } \\
& \mathrm{CF}=\text { Capacity Factor (0.8) } \\
& D C=\text { Disposal Cost (25.00/MT Sulfur) } \\
& I B=\text { Purchased Equipment Cost in the Design Facility }(\$ 2,400,000) \\
& \text { MR = Mole Ratio ( } 3 \text { Moles } \mathrm{H}_{2} \mathrm{O}_{2} / 1 \text { Mole } \mathrm{H}_{2} \mathrm{~S} \\
& \text { MW1 = Mole Weight (34 lb } \mathrm{H}_{2} \mathrm{O}_{2} / 1 \text { Mole } \mathrm{H}_{2} \mathrm{O}_{2} \text { ) } \\
& \text { MW2 = Mole Weight }\left(1 \text { Mole } \mathrm{H}_{2} \mathrm{~S} / 34 \mathrm{lb} / \mathrm{H}_{2} \mathrm{~S}\right) \\
& \text { NT }=\text { Number of } \mathrm{H}_{2} \mathrm{O}_{2} \text { Tanks Needed ( } 1 \text { Tank) } \\
& P C=\text { Peroxide Cost ( } \$ 19.00 / 100 \mathrm{lb} \mathrm{H}_{2} \mathrm{O}_{2}, 35 \% \text { Solution) } \\
& \mathrm{PE}_{1980}=\text { Purchased Equipment cost in } 1980 \text { dollars } \\
& \mathrm{PH}_{2} \mathrm{~S}=\mathrm{H}_{2} \mathrm{~S} \text { Flow Rate Through Facility (1b/yr) } \\
& S R=\text { Solution Ratio (100 } \mathrm{Ib} \mathrm{H}_{2} \mathrm{O}_{2} \text { Solution/35 } \mathrm{lb} \mathrm{H}_{2} \mathrm{O}_{2} \text { ) } \\
& \text { SRE = System Removal Efficiency (.96) } \\
& T C=\text { Tank Cost }(\$ 13,750 / \text { tank }) \\
& \text { WF }=\text { Brine Flow Rate }(500,000 \mathrm{lb} / \mathrm{hr}) \\
& X=\text { Equipment Sizing Factor (0.85) }
\end{aligned}
$$

CONTROL COSTS - EIC

Several cost estimates are available for the EIC process. The process is undergoing testing and demonstration at The Geysers because of its very high removal efficiency and its upstream treatment benefits. 


\section{Purchased Equipment}

Previous cost estimates from EIC have been reviewed and evaluated by numerous authors in the literature (EPA 1978; Midwest Research Institute 1978; Sung 1977). However, a current cost estimate from EIC for a 110 MWe sized $\mathrm{H}_{2} \mathrm{~S}$ treatment design was used as the basis for cost estimates in this report. Based on the literature reviews and on the estimates provided to PNL by EIC, a purchased equipment cost function has been developed below. Equipment required includes scrubbers, reactors, tankage, pumps and agitators, heat exchangers, and liquid-solid separation facilities. The steam flow rate will size the steam scrubbers.

\section{Operating Costs}

Estimates of operating costs have been prepared by EIC for specific conditions at The Geysers (EIC Corporation 1978). Process costs are sensitive to $\mathrm{H}_{2} \mathrm{~S}$ flow rates and can be expressed both in terms of capital investment and mass flow rates.

\section{EQUATION B.2. EIC Process $\mathrm{H}_{2} \mathrm{~S}$ Abatement Cost Functions}

$$
\begin{aligned}
\mathrm{PE}_{1980}= & P 1 \times \mathrm{IB} \times(\mathrm{SA} / \mathrm{SB})+\mathrm{P} 2 \times \mathrm{IB} \times(\mathrm{HA} / \mathrm{HB})^{\mathrm{X}} \\
\mathrm{AOC}_{1980}= & (\mathrm{LU} \times \mathrm{LC})+(\mathrm{THR} \times \mathrm{CF}) \times[(\mathrm{ER} \times \mathrm{EC})+(\mathrm{WR} 1 \times \mathrm{OC})+(\mathrm{WR2} \times \mathrm{AC}) \\
& +(\mathrm{WR3} \times \mathrm{CC})+(\mathrm{WR} 4 \times \mathrm{HC})+(\mathrm{RR} \times \mathrm{RC})]+\mathrm{MR} \times \mathrm{PE}_{1980}
\end{aligned}
$$

Variables:

$$
\begin{aligned}
& A C=\mathrm{NH}_{3} \operatorname{Cost}\left(\$ 190 \mathrm{MT} \mathrm{NH}_{3}\right) \\
& A O C_{1980}=\text { Annual Operating Cost in January } 1980 \text { dollars } \\
& \mathrm{CC}=\mathrm{CuSO}_{4} \operatorname{Cost}\left(\$ .815 / \mathrm{Tb} \mathrm{CuSO}_{4}\right) \\
& C F=\text { Capacity Factor (0.80) } \\
& E C=\text { Electricity Cost }(\$ 0.043 / \mathrm{kWh}) \\
& \left.E R=\text { Electricity Ratio (1210 kWh/MT } \mathrm{H}_{2} \mathrm{~S}\right) \\
& H A=H_{2} S \text { Concentration in the Proposed Facility }\left(\mathrm{ppm}_{\mathrm{W}}\right) \\
& \mathrm{HB}=\mathrm{H}_{2} \mathrm{~S} \text { Concentration in the Design Facility }\left(240 \mathrm{ppm}_{\mathrm{W}}\right)
\end{aligned}
$$


$\mathrm{HC}=\mathrm{H}_{2} \mathrm{SO}_{4} \operatorname{Cost}\left(\$ 0.030 / 1 \mathrm{~b} \mathrm{H} \mathrm{H}_{2} \mathrm{SO}_{4}\right)$

$I B=$ Purchased Equipment Cost in the Design Facility $(\$ 4,500,000)$

$L C=$ Labor Cost ( $\$ 16.80 /$ Manhour $)$

$L U=$ Labor Units ( 8320 Manhours/yr)

$M R=$ Maintenance Rate $(0.065)$

$O C=0_{2}$ Cost $\left(\$ 90 / M T O_{2}\right)$

P1 = Percent of Represented by Scrubbers (0.75)

P2 = Percent of Purchased Equipment Determined by $\mathrm{H}_{2} \mathrm{~S}$ Concentration (0.25)

$\mathrm{PE}_{1980}=$ Purchased Equipment Cost in 1980 Dollars

$R C=\operatorname{Resin}$ Cost $\left(\$ 115.00 / \mathrm{ft}^{3}\right.$ Resin)

$R R=$ Resin Ratio (0.0686 $\mathrm{ft}^{3}$ Resin/MT $\mathrm{H}_{2} \mathrm{~S}$ )

$S A=$ MWe (gross) of the Proposed Facility

$S B=$ MWe (gross) of Design Facility (110)

THR $=\mathrm{H}_{2} \mathrm{~S}$ Flow Rate Through Facility at $100 \%$ of Rated Capacity (MT/yr)

WR1 = Weight Ratio of $\mathrm{O}_{2}\left(1.025 \mathrm{MT} \mathrm{O}_{2} / \mathrm{MT} \mathrm{\textrm {H } _ { 2 } \mathrm { S } )}\right.$

WR2 = Weight Ratio of $\mathrm{NH}_{3}\left(0.25 \mathrm{MT} \mathrm{NH}_{3} / \mathrm{MT} \mathrm{H}_{2} \mathrm{~S}\right)$

WR3 = Weight Ratio of $\mathrm{CuSO}_{4}\left(17.6 \mathrm{lb} \mathrm{CuSO}_{4} / \mathrm{MT} \mathrm{H}_{2} \mathrm{~S}\right)$

WR4 = Weight Ratio of $\mathrm{H}_{2} \mathrm{SO}_{4}\left(68.6 \mathrm{lb} \mathrm{H}_{2} \mathrm{SO}_{4} / \mathrm{MT} \mathrm{H}_{2} \mathrm{~S}\right)$

$X=$ Equipment Sizing Factor $(0.60)$

CONTROL COSTS-STRETFORD

Because of the Stretford's wide acceptance as an $\mathrm{H}_{2} \mathrm{~S}$ control process, relatively reliable cost estimates are available for it.

\section{Purchased Equipment}

Larry Krumland of PG\&E reports that the additional cost of substituting a surface condenser for a direct contact condenser at The Geysers is expected to be approximately $\$ 1.1$ million. Each Stretford unit will cost approximately $\$ 3.8$ million, bringing the total purchased equipment cost in (January 1980 dollars) for a surface condenser and Stretford plant to $\$ 4.9$ million. These plants are designed to handle the 3000 standard cubic feet per minute (scfm) 
noncondensible gas flow of the 110 MWe generating units described earlier. $\mathrm{H}_{2} \mathrm{~S}$ design treatment capacity of $600 \mathrm{lb} / \mathrm{hr}$ corresponds to an expected $\mathrm{H}_{2} \mathrm{~S}$ concentration maximum of $300 \mathrm{ppm}_{\mathrm{w}}$. These costs represent the base case from which functional extrapolations will be made. The $\$ 4.9$ million estimate includes direct engineering, material, and labor, but not general overheads, general engineering, administrative expenses, construction interest, or ad valorem constructon taxes, all of which might add 20 to $30 \%$ in a typical installation at The Geysers. Based on literature reviews and on information provided by Mr. Krumland at PG\&E and Mr. Alex Ingles of the R. M. Parsons Company, a purchased equipment cost function has been developed. Equipment required includes not only the surface condensers mentioned earlier, but also an oxidizer tank, skim tank, surge tank, centrifugation and heating units, and the associated instrumentation.

\section{Operating Costs}

Estimates of operating costs for a Stretford system have been prepared by several sources (Bowen 1973; Mariner 1974; Mariner 1976). Operating costs are directly related to $\mathrm{H}_{2} \mathrm{~S}$ flow rates in a linear relationship.

\section{EQUATION B.3. Stretford Process Cost Functions}

$$
\begin{aligned}
\mathrm{PE}_{1980}= & \mathrm{IB} \times(\mathrm{SDA} / \mathrm{SDB})^{\mathrm{X}} \\
\mathrm{AOC}_{1980}= & (L C \times L U)+(\text { THR } \times C S \times C F) \times[(E R \times E C)+(\text { WR1 } \times A C)+(\text { WR2 } \times \text { VC }) \\
& +(\text { WR3 } \times \mathrm{NC})-(\text { SR } \times \text { SRE } \times S C)]
\end{aligned}
$$

Variables:

$$
\begin{aligned}
A C & =\text { ADA Cost }(\$ 5.25 / 1 \mathrm{~b} \text { ADA }) \\
\mathrm{AOC}_{1980} & =\text { Annual Operating Cost in January } 1980 \text { dollars } \\
\mathrm{CF} & =\text { Capacity Factor }(0.80) \\
\mathrm{CS} & =\text { Condenser } \mathrm{H}_{2} \mathrm{~S} \text { Split }(0.90) \\
\mathrm{EC} & =\text { Electricity Cost }(\$ 0.043 / \mathrm{kWh}) \\
E R & =\text { Electricity Ratio }\left(380 \mathrm{kWh} / \mathrm{MT} \mathrm{H}_{2} \mathrm{~S}\right)
\end{aligned}
$$




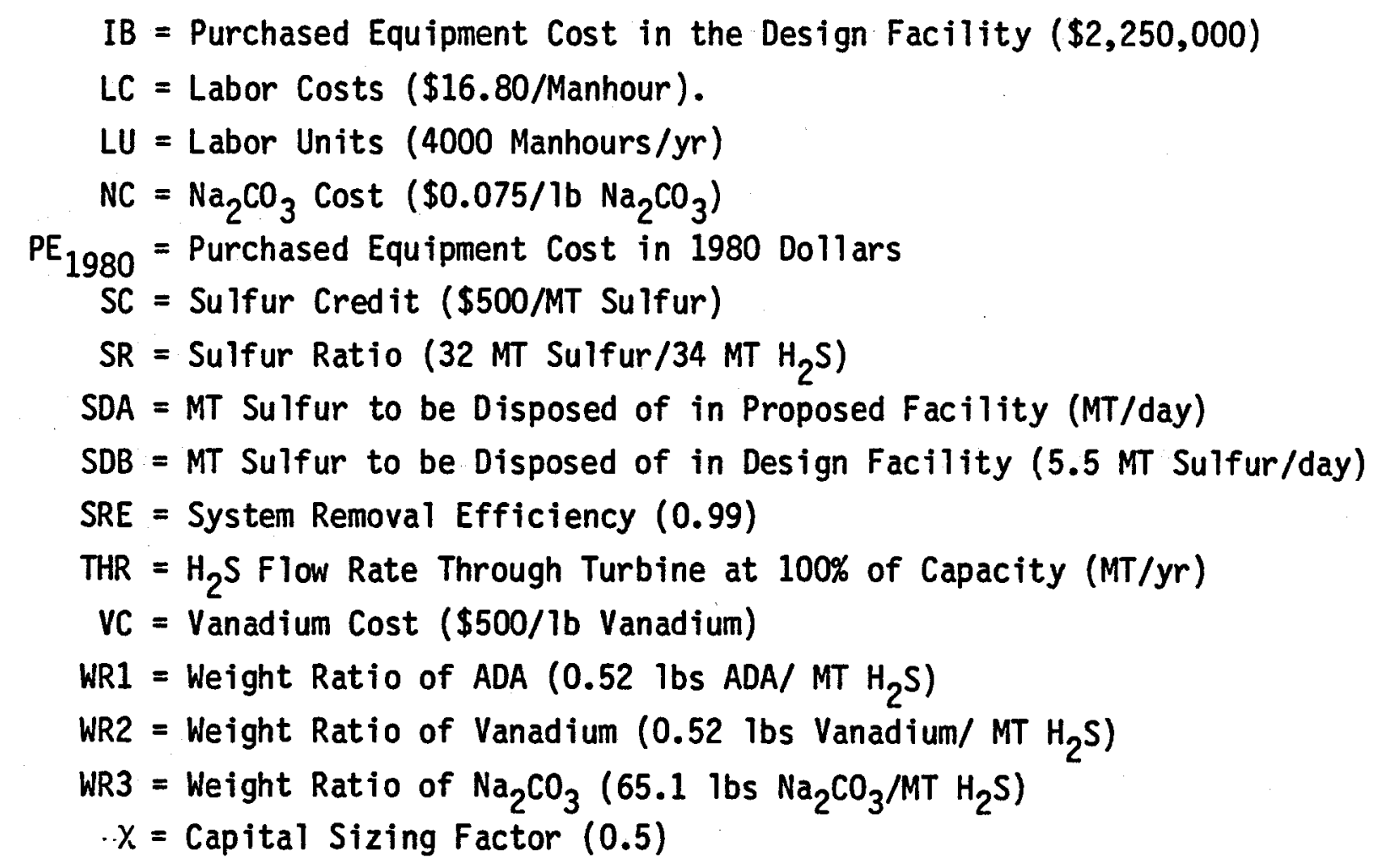

\section{CONTROL COSTS - PEROXIDE PROCESS}

The estimated costs of treating condensate that contains $\mathrm{H}_{2} \mathrm{~S}$ from surface condensers have been developed by SRI for a specific unit at The Geysers. Purchased Equipment

A purchased equipment cost function was developed from SRI estimates of filtration and pipeline reactor costs. No information that relates these costs to variations in the $\mathrm{H}_{2} \mathrm{~S}$ concentration in the condensate is available. Based on experience with other abatement cost functions, costs are expected to depend on the steam flow rates.

\section{Operating Costs}

Total operating costs are dominated by the high cost of $\mathrm{H}_{2} \mathrm{O}_{2}$. Power requirements are expected to be insignificant. 
EQUATION B.4. Peroxide Process Cost Functions

$$
\begin{aligned}
P_{1980}= & I B F \times(S A / S B)^{X}+I B P \times(S A / S B) \\
A O C C_{1980}= & (L C \times L U)+\left(P H_{2} S \times C S \times C F\right) \times[(W R 1 \times H C \times S R) \\
& +(S R E \times M W R \times C 1 \times D C)]
\end{aligned}
$$

Variables:

$$
\begin{aligned}
& { }^{A O C}{ }_{1980}=\text { Annual Operating Cost in January } 1980 \text { Dollars } \\
& \text { CF }=\text { Capacity Factor }(0.80) \\
& \mathrm{CS}=\text { Condensate } \mathrm{H}_{2} \mathrm{~S} \mathrm{Split}\left(\frac{0.10 \mathrm{lbs} \mathrm{H}_{2} \mathrm{~S} \text { Condensate }}{1.00 \mathrm{lbS} \mathrm{H}_{2} \mathrm{~S} \text { Steam }}\right) \\
& \mathrm{C1}=\text { Constant (1 MT/2205 lbs) } \\
& D C=\text { Disposal Cost (25.00/MT Sulfur) } \\
& \mathrm{HC}=\mathrm{H}_{2} \mathrm{O}_{2} \text { Cost ( } \$ 16.50 / 100 \text { lbs } \mathrm{H}_{2} \mathrm{O}_{2} 35 \% \text { Solution) } \\
& \text { IBF }=\text { Purchased Equipment Cost in Design Filtration Unit }(\$ 230.000) \\
& I B P=\text { Purchased Equipment Cost in Design Pipeline System }(46,000) \\
& L C=\text { Labor Cost (\$16.80/Manhour) } \\
& L U=\text { Labor Units (2112 Manhours/yr) } \\
& \text { MT }=\text { Metric Tons } \\
& \text { MNR = Molecular Weight Ratio (32 lbs } \mathrm{S} / 34 \text { lbs } \mathrm{H}_{2} \mathrm{~S} \text { ) } \\
& \mathrm{PE}_{1980}=\text { Purchased Equipment Cost in } 1980 \text { do } 11 \text { ars } \\
& \mathrm{PH}_{2} \mathrm{~S}=\text { Total } \mathrm{H}_{2} \mathrm{~S} \text { Flow Rate Through Turbine at Full Capacity (1b/yr) } \\
& S A=\text { Steam Flow Rate in Proposed Facility (1b/yr) } \\
& S B=\text { Steam Flow Rate in Design Facility }\left(1 \times 10^{6} \mathrm{lb} / \mathrm{yr}\right) \\
& S R=\text { Solution Ratio (100 } \mathrm{lb} \mathrm{H}_{2} \mathrm{O}_{2} \text { Solution/35 lbs } \mathrm{H}_{2} \mathrm{O}_{2} \text { ) } \\
& \text { SRE = System Removal Efficiency (0.99) } \\
& \text { WR1 = Weight Ratio of } \mathrm{H}_{2} \mathrm{O}_{2}\left(1 \mathrm{lb} \mathrm{H}_{2} \mathrm{O}_{2} / \mathrm{lb} \mathrm{H}_{2} \mathrm{~S}\right) \\
& X=\text { Equipment Sizing Factor }(0.40) \\
& y=\text { Equipment Sizing Factor }(0.20)
\end{aligned}
$$




\section{CONTROL COSTS - IRON CATALYST PROCESS}

Available cost estimates for the Iron Catalyst system come from PG\&E at The Geysers in California where the process was developed and installed. By design it is a mechanically and chemically simple system.

Purchased Equipment

The following relationships have been estimated by EPA to explain the purchased equipment cost of the system (Bowen 1973):

(1) Cost of the proposed unit is a function of the cooling water flow rate.

(2) Cooling water flow rate is a function of the steam flow rate.

(3) Therefore, the steam flow rate is an acceptable cost modeling variable.

(4) Purchased equipment costs are assumed to be independent of the $\mathrm{H}_{2} \mathrm{~S}$ concentration, given the existing need for control.

\section{Operating Costs}

Several sources have prepared estimates of operating costs for the basic Iron Catalyst process (Parsons 1975; Mariner 1974a). No cost estimates are available for the peroxide modified system. Technical relationships have also not yet been worked out for the modified process, so all costs below are for the basic unmodified system. Operation and maintenance costs were assumed to be linearly dependent on two factors (Bowen 1973):

(1) steam flow rate, with $\mathrm{H}_{2} \mathrm{~S}$ concentration constant

(2) $\mathrm{H}_{2} \mathrm{~S}$ concentration, with steam flow rate constant.

\section{EQUATION B.5. Iron Oxide Process Cost Functions}

$$
\begin{aligned}
\mathrm{PE}_{1980}= & \mathrm{IB} \times(\mathrm{SA} / \mathrm{SB})^{\mathrm{X}}+[\mathrm{CC}+(\mathrm{CI} / \mathrm{SA})] \\
\mathrm{AOC}_{1980}= & (\mathrm{LC} \times \mathrm{LU})+(\mathrm{PS} \times \mathrm{CF} \times \mathrm{ER} \times \mathrm{EC})+\left(\mathrm{PH}_{2} \mathrm{~S} \times \mathrm{CF}\right) \times[(W R 1 \times N C) \\
& \left.(\text { WR2 } \times \mathrm{SC})+(\mathrm{WR} 3 \times \mathrm{FC})+\left(\mathrm{CF} \times \mathrm{PH}_{2} \mathrm{~S} \times \mathrm{SRE} \times \mathrm{DC}\right)\right]
\end{aligned}
$$


Variables:

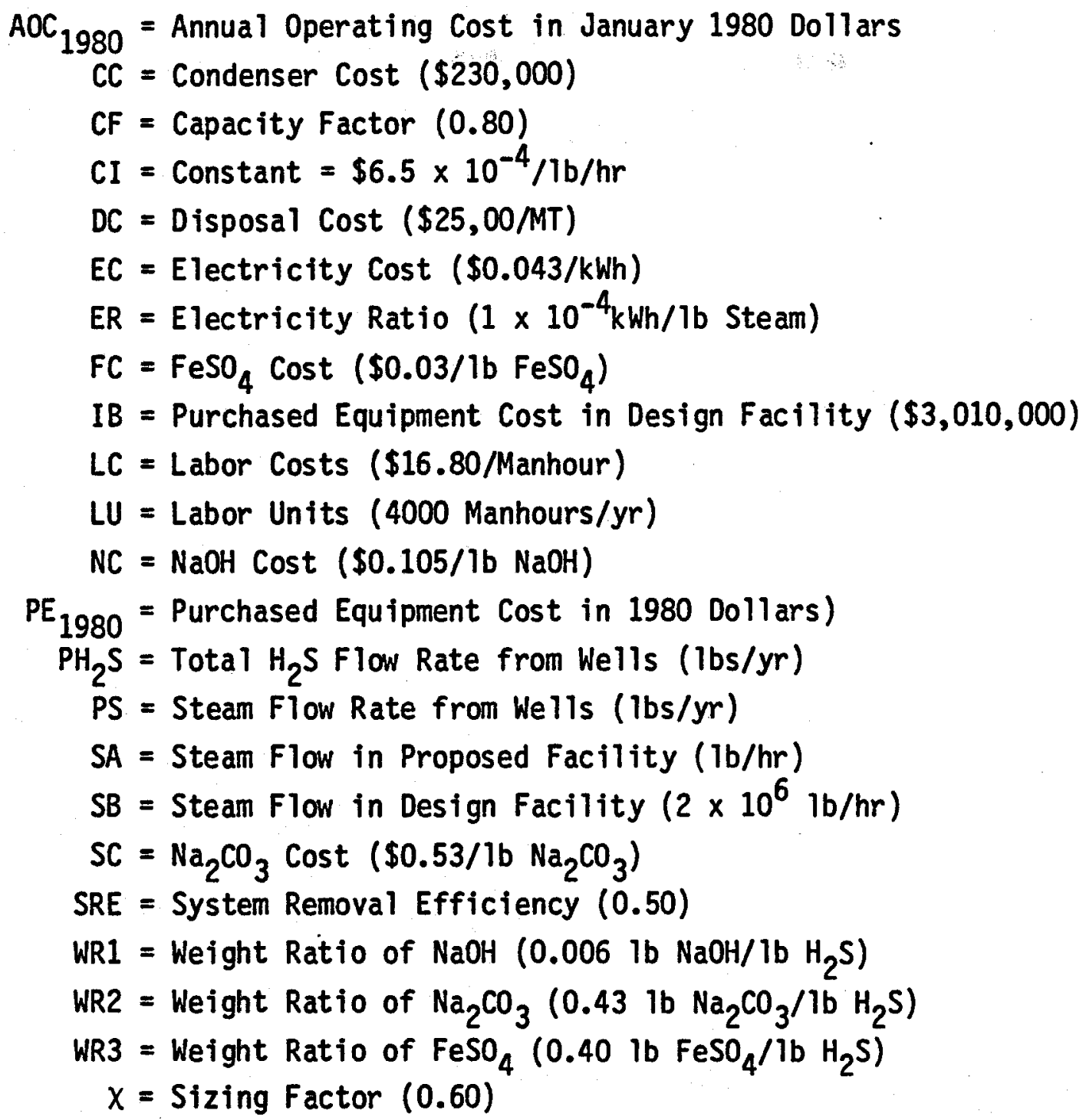


APPENDIX C

$\underline{H}_{2}$ S ABATEMENT COSTS 


\section{APPENDIX C}

\section{$\mathrm{H}_{2} \mathrm{~S}$ ABATEMENT COSTS}

TABLE C.1. Hydrogen Sulfide Abatement Costs(a)

\begin{tabular}{|c|c|c|c|c|c|c|}
\hline \multirow{3}{*}{ Process } & \multicolumn{6}{|c|}{ Control Level } \\
\hline & & & & & & \\
\hline & $\$ / y r$ & Mills/kWh & $\$ / y r$ & Mil1s/kWh & $\$ / y r$ & Mills/kWh \\
\hline $\begin{array}{l}\text { Stretford } \\
\text { Peroxide }\end{array}$ & $\$ 972,000$ & 1.35 & $\$ 1,281,000$ & 1.78 & $\$ 3,303,000$ & 4.59 \\
\hline EIC & $\$ 1,608,000$ & 2.23 & $\$ 2,393,000$ & 3.32 & $\$ 2,554,000$ & 3.55 \\
\hline
\end{tabular}

(a) All Costs are in January 1980 dollars. Annual output of $7.2 \times 10^{8} \mathrm{kWh}$. 
APPENDIX D

COST ESTIMATION METHODOLOGY 


\section{APPENDIX D}

\section{COST ESTIMATION METHODOLOGY}

The cost of meeting geothermal environmental standards is determined by several factors including, but not limited to, the capital and operating costs associated with employing environmental control technology (ECT). This report focuses strictly on the expenditures directly attributable to the use of ECT. (a) A discounted cash-flow capital-budgeting methodology is presented in this appendix to describe the procedure used to estimate the costs of employing geothermal environmental control technology.

THE CAPITAL BUDGETING MODEL

A discounted cash-flow framework that expresses the life-cycle costs of employing ECT in terms of levelized costs per kWh has been selected for use in this report. Selection of a discounted cash-flow methodology is in accord with economic theory, with practice in both public and private utilities, and with current DOE and EPRI methodologies (Colborn and Cronin July 1979).

The procedure calculates the impact that the use of environmental control processes may have on the busbar cost of producing electricity from a utilityowned geothermal electric system. This approach is applicable to both publicly and privately owned utilities. Busbar cost represents the minimum price per kWh that will produce revenues equal to the sum of energy-production costs and environmental-control-system-related costs. This equality is expressed in present value terms; the real discount rate used reflects the real after-tax

(a) Additional costs that are imposed by the existence of environmental regulations include, for example, the expense of maintaining a legal staff to comply with and interpret, lobby, and testify on new, existing, and/or proposed standards. Although the magnitude of indirect regulatory costs may be significant, the quantification of such costs is beyond the scope of this imediate research effort. 
cost of capital to the firm. Data are needed on variables that describe the output capabilities and capital cost of the treatment systems, the real cash flows required for system operation and maintenance, and the financial structure and tax environment of the utility. The analysis will identify the most cost-effective liquid-waste-treatment system for geothermal applications. The cost-estimation procedures adopted here require neither computer software nor expertise in financial management for their successful use.

The basic approach requires the user to develop an estimate of those costs incurred by a utility as the result of purchasing, installing, and operating a given abatement system. These costs are expressed in real (inflationadjusted) dollars on a yearly basis. The total annual costs are then divided by the expected yearly energy output of the specific geothermal plant. The result is an estimate of the change in the busbar cost of energy from the system that is attributable to operating the environmental control technology. If the system were to produce exactly its expected net energy output and if that output were "sold" at a price equal to the sum of the estimated production costs and environmental control system costs, the resultant revenues would exactly recover the full costs of the system over its lifetime. The full cost includes compensation to creditors and investors for the real (inflation-free) opportunity cost of their committed funds.

Use of the cost estimation procedure requires definition of specific cost-determining variables and selection of accurate price and quantity coefficients for those variables. Second, a simple algorithm is required to compute costs per kWh. Finally, the cost estimates need to be interpreted and analyzed to draw meaningful conclusions from the results of the procedure. The factors influencing the results are discussed in the subsection dealing with the investment climate.

Cost-Determining Variables

Experience dictates that the most accurate and useful characterization of the flow of funds (revenues and expenditures) associated with long-lived capital investment projects consists of classifying cash flows as either fixed or variable. With environmental control technology, the focus is on minimizing 
the cost of meeting environmental standards. Therefore, the discussion will deal mainly with fixed and variable costs. Fixed costs include both initial capital investments in land, plant, operating equipment, and interim capital replacements. In addition, any periodically recurring expenditures that may best be approximated as a fraction of the initial capital investment, such as property taxes and insurance fees, may also be categorized as fixed costs. Variable costs include the annual expenditures for fuel, maintenance, and labor inputs to the production process. Any revenues generated during a given operating period (e.g. through the sale of reclaimed emissions or effluents) would be treated as variable but positive cash flows.

Financial Variables

A technical (engineering-oriented) investigation of the environmental control process is required to estimate the particular physical conditions that will prevail during operation of the environmental control processes at a specific site. These physical conditions, coupled with environmental standards, make possible the estimation of the least-costly combination of fixed and variable production factors required by the treatment process to meet the given standards. From these estimates and from market prices, projections of the required capital investment (fixed costs) and required annual operating expenditures (variable costs) may be generated for the geothermal facility. Table D.1 presents a description of the financial variables used in the estimation procedure and their values assumed for purposes of this report. Note that a weighted average real after-tax cost of capital (WACC) of $10 \%$ has been assumed for purposes of computing the cost of using the environmental control processes.

\section{The Cost Algorithm}

Using the appropriate variables, as defined in Table 0.1, the Levelized Total Annual Cost in January 1980 dollars of employing environmental control technology may be expressed symbolically as:

$$
\operatorname{LTAC} \frac{\text { mills }}{\mathrm{kWh}}(\$ 1980)=\frac{\operatorname{LAFC}+\operatorname{LAOC}(\$ 1980)}{\mathrm{kWh} / \mathrm{yr}}
$$




\section{TABLE D.1. Variables for Cost Estimation}

Symbol

$P E_{R Y}$

LAFC

LAOC

LTAC

N

B

$\mathrm{CI}_{\mathrm{xxxx}}$

DCI

ICI

CCI

CF

IDC

d

FCR

CRF

PF

\section{Description}

Cost of Purchased Equipment in Reference Year

Levelized Annual Fixed Costs

Levelized Annual Operating Costs

Levelized Total Annual Cost

System Lifetime

Construction Period

Capital Investment. Subscripts will indicate in which years' dollars the estimate is denominated.

Direct Capital Investment

Indirect Capital Investment

Contingency Capital Investment

Contractors' Fees

Interest During Construction Factor

Real Discount Rate

Real Fixed Charge Rate

Depreciation Tax Shield

Insurance

Local Taxes

Maintenance and Repairs

Administration

Capital Recovery Factor

Geothermal Plant Capacity Factor

\section{Assumed Value}

As given in the literature

Endogenously determined

LAFC + LAOC

30 years

3 years

Endogenously determined $=\mathrm{DCI}+\mathrm{ICI}$

$+\mathrm{CCI}+\mathrm{IDC}+\mathrm{CF}$

Purchiased equipment at cost ( $\left.P E_{R Y}\right)$ plus installation e $35 \%$ (PE)

Engineering $20 \% \mathrm{OCI}$

Construction $0 / \mathrm{HC} 20 \%$ DCI

Engineering and construction overheads $30 \%$ (DCI + ICI)

$10 \%(C C I+D C I+I C I)$

Estimated by the following equation, which assumed a linear investment expenditure pattern:

$=0.16=1-\left(\frac{1+d}{1}\right) \frac{\left(\frac{1}{1+d}\right)^{B}-1}{B \ln \frac{1}{1+d}}$

Real WACC after taxes:

$d=K d \frac{D}{D+E}+K e \frac{E}{D+E}=10 \%$

Derived as the sum of insurance, local tax, administrative, maintenance, and capital recovery factor rates $=15 \%$

o $-1.6 \% \mathrm{CI}$

(c) $1 \% \mathrm{CI}$

(a) $2 \% \mathrm{CI}$

c) $2 \% \mathrm{CI}$

a $1 \%$ CI

$\frac{d}{(1+d)^{N}-1}+d=10.6$

$80 \%$ 
Intermediate stages in the procedure are outlined below in a series of thirteen steps:

1. Calculate purchased equipment cost estimates from the control cost functions developed in this report. Purchased equipment costs are stated in January 1980 dollars as: $\mathrm{PE}_{1980}$

2. Calculate the direct and indirect capital investment overheads to $P E_{1980}$ :

$$
\begin{aligned}
D C I & =.35 \mathrm{PE}_{1980} \\
C I & =.4 \mathrm{DCI}=.14 \mathrm{PE}_{1980}
\end{aligned}
$$

3. Calculate the contingency overhead to $\mathrm{PE}_{1980}$ : $\mathrm{CCI}=0.30$ (ICI +

$$
D C I)=.15 \mathrm{PE}_{1980}
$$

4. Estimate the contractors' fees:

$$
C F=0.10(D C I+I C I+C C I)=0.06 \mathrm{PE}_{1980}
$$

5. Calculate interest during construction:

$$
\begin{aligned}
I D C & =.16 P E_{1980}+C C I+D C I+I C I+C F \\
& =.16 P E_{1980}+P E_{1980}(.35+.14+.15+.06) \\
& =.27 \mathrm{PE}_{1980}
\end{aligned}
$$

6. Calculate total capital investment in January 1980 dollars

$$
\begin{aligned}
C I_{1980} & =P E_{1980}+C C I+D C I+I C I+I D C+C F \\
& =P E_{1980}+P E_{1980}(.35+.14+.15+.06+.27) \\
& =1.97 \mathrm{PE}_{1980}=2.0 \mathrm{PE}_{1980}
\end{aligned}
$$

This excludes installation, which may add approximately $125 \%$ of PE to $\mathrm{CI}_{1980}$.

7. Estimate the Real Annual Fixed Capital Charges (AFC) applied to $\mathrm{CI}_{1985}$ using Real (Fixed Charge Rate) FCR:

Capital Recovery Factor: 10.6\%

Depreciation Tax Shield $\quad 1.6 \%$

Insurance $\quad 1.0 \%$

Local Property or

Revenue Taxes 2\%

Maintenance \& Repairs $2 \%$

Administrative Overhead $\quad \underline{0.2 \%}$

Fixed Charge Rate $\quad 15.00 \%$ 


$$
\text { LAFC }_{1980}=0.15 \times \mathrm{CI}_{1980}=0.15 \times\left(2.0 \mathrm{PE}_{1980}\right)=0.30 \mathrm{PE}_{1980}
$$

8. Obtain an estimate of the annual operating costs (AOC) in 1980 dol1 ars, as given by the cost functions for individual treatment processes.

9. If relative capital and operating costs are assumed not to change, then the present value of a 30 -year stream of operating costs using the $10 \%$ WACC is equal to the levelized present value of the future operating costs using the real WACC in a capital recovery factor. Thus, the $A C_{1980}$ estimate may be used directly as the LAOC $_{1980}$.

10. Add the annual operating costs (in 1980 dollars) to the levelized annual fixed charges (in 1980 dollars) to find the levelized total annual cost LTAC $_{1980^{\circ}}$ Convert to mills/yr (1980) by multiplying by $10^{3}$.

11. Using the plant capacity factor, compute the expected annual net $k$ Wh production (kWh/yr).

12. Compute the cost of using the environmental control technology per unit of energy: LTAC $_{1980} / \mathrm{kWh}$ per year. Note that installation may add approximate $7 y$ 125\% of PE to bring LAFC 1980 up to 0.50 $\mathrm{PE}_{1980}$. When the given values are used, this entire procedure simplifies to:

1) $\quad \mathrm{LAFC}_{1980}=\mathrm{PE}_{1980} \times 2.0 \times .15=0.30 \mathrm{PE}_{1980}$

2) $A O C C_{1980}=L_{A O C} 1980$ (from cost functions)

3) $\frac{\text { mills }}{\mathrm{KWh}}=\mathrm{LAFC}_{1980}+$ LAOC $_{1980} \frac{10^{3} \text { mills }}{\$} \times \frac{1 \mathrm{yr}}{\text { kWh production }}$

Note that the payback period for the purchased equipment is approximately three years, based on the results of steps 7 .

\section{INVESTMENT CLIMATE}

The commercialization of geothermal resources requires at least two distinct corporate entities: a resource developer to provide geothermal steam to 
the power plant, and a (regulated) utility that uses the steam to generate electricity. Discussion here will focus on the utility as the main entity of interest and the implications of that selection for the cost of employing environmental control technology (ECT).

Regulated Utilities

The utility is emphasized in this report because their WACC is the relevant discount rate for the capital budgeting analyses of ECT. The geothermal resource developer who performs the functions of well field exploration and fluid/steam transmission facility siting is not expected to employ the type of ECT that is investigated here and that will be required during the facility's operating phase. Instead, the developer will only provide the geothermal fluid to the production facility (generating unit) and, thereby, avoid the possibility of becoming regulated as a public utility. Such regulation could place a ceiling on the allowable rate of return. Because that ceiling might be below the developer's weighted average cost of capital, the developer would be prevented from earning a rate of return on well-field exploration and development activities sufficient to compensate for the higher risks involved. As a result, the potential to profitably undertake ventures would be reduced or eliminated.

The utility rate structure is, therefore, relevant to an evaluation of capital budgeting for geothermal ECT. Rates are set at a level sufficient to recover invested capital plus the utilities' opportunity cost of that capital as represented by the utilities' real after-tax WACC. Determinants of the real, after-tax WACC used in the costing methodology include the income tax, inflation, and risk factors present in the utilities' environment.

Income Tax Factors

Accelerated depreciation in excess of either the sum of the years' digits or double declining balance (SYD or DDB) is not allowed on pollution control equipment on geothermal facilities put into operation after January 1, 1976. The maximum allowable IRS tax life for electric-generatng facilities is 22.5 years; therefore, this report's use of a 30 -year economic life and 
straight-line depreciation (SLD) with no tax preference item allowance may actually overstate the present value of the after-tax cash outflows attributable to capital recovery for ECT systems. (a)

Investment tax credits (ITC) are allowed on geothermal capital investments and presumably would also be allowed on ECT. In this report the ITC has not been included in the analysis. This exclusion has the effect of overstating the life-cycle costs of capital-intensive ECT relative to operating costintensive processes. Income (revenue) generated by the utility is expected to be taxed at a marginal rate of $46 \%$, providing a tax shield on debt interest expense on $7 y_{.}{ }^{(b)}$ Depending on relative weights of debt and equity in the firm's capitalization, these tax effects will influence the discount rate of the regulated utility.

\section{Risk and Inflation Factors}

In addition to the influence of income tax factors, both industry risk and expected price-level changes may be significant determinants of the real, after-tax WACC facing a utility. With respect to geothermal risk factors, the premium attached to the real riskless rate of return available in short-term government securities (T-Bills) will be determined by the following items:

- system reliability

- temperature and flow rate declines over time

- changing environmental regulations

- rapid technological advances in ECT systems.

These items are meant to represent the nondiversifiable risks associated with capital investments in ECT for geothermal resources (i.e., the marginal or incremental risks that characterize investments in geothermal facilities as opposed to less risky investments in T-Bills).

(a) The magnitude of overestimation is not expected to be significant relative to the uncertainty surrounding price estimates for the purchased equipment.

(b) The cost of equity to the firm is equal to the rate of return demanded by investors. No tax deduction is available to the firm for their equity costs. From the firm's standpoint, both the before- and after-tax cost of equity capital is the same. 
A risk premium would be attached to discount rates only if the investment in geothermal facilities influences the firms' expected marginal cost of capital (in that case, the WACC is an inappropriate hurdle rate or decision criterion and the marginal cost of capital is used in its place). Because this report assumes that investments by a utility in geothermal facilities will not change the marginal cost of capital, a risk-adjusted real after-tax WACC was used as the theoretically appropriate accept/reject investment criterion.

The final source of impact on the appropriate WACC, which is used in discounting future cash flows, arises from expected changes in the general price level (inflation). In this study the inflation premium has been eliminated from the analysis. All cash flows and discount rates reflect real (constant) January 1980 dollars. Relative price changes for factors and products are assumed to be negligible; thus, the discount rate "d" is applicable to all future cash flows. 
DISTRIBUTION

No. of

Copies

OFFSITE

A. A. Churm

DOE Patent Division

9800 S. Cass Avenue

Argonne, IL 60439

27 DOE Technical Information Center

10 Robert 01iver

Resource Applications

Department of Energy

Room 7119

12th and Pennsylvania Ave. N.W.

Washington, DC 20545

Randall Stephens

Resource Applications

Department of Energy

Room 7119

12th and Pennsylvania Ave. N.W.

Washington, DC 20545

4 Fred Abel

Resource Applications

Department of Energy

Room 7119

12th and Pennsylvania Ave. N.W. Washington, DC 20545

Vasel Roberts

Electric Power Research Institute

3412 Hillview Avenue

Palo Alto, CA 94304

W. P. Jensen

EG\&G Idaho, Inc.

Idaho National Laboratory

Idaho Falls, ID 83401
No. of

Copies

Car 1 Weinberg

Pacific Gas \& Electric Co.

77 Beale

San Francisco, CA 94106

Gilbert L. Lombard

San Diego Gas \& Electric Co.

P.0. Box 1831

San Diego, CA 92112

R. Lyon

Oak Ridge National Laboratory

P.0. Box $X$

Oak Ridge, TN 37830

G. Brandvold

Sandia Corporation

Albuquerque, NM 87115

Joel Robertson

Union 0 il Co.

Box 7600

Los Ange les, CA 90051

Jack Maddox

Public Service Co. of New Mexico

P.0. Box 2267

Albuquerque, NM 87103

Ben Holt

The Ben Holt Co.

201 South Lake Avenue

Pasadena, CA 91101

Thomas Casse 1

Technecon Analytic Research, Inc.

2400 Chestnut Street

Philadelphia, PA 19103 
No. of

Copies

James Kuwada

Rogers Engineering

111 Pine Street

San Francisco, CA 94111

Roger Sung

TRW

One Space Park

Redondo Beach, CA 90278

John Wilson

Dow Chemical Company

Freeport, TX 77541

Kenneth F. Mirk

Lawrence Berkeley Laboratory

Berkeley Laboratory 94720

L. J. P. Muffler

U. S. Department of Interior

Office of Geochemistry \&

Geophysics

345 Middlefield Road

Men lo Park, CA 94025

Alan D. Grant

Portland General Electric Co.

621 Southwest Alder

Portland, OR 97205

Jim Galeski

Black and Veatch

P.0. Box 8405

Kansas City, MO 64114

R. B. Corye 11

Geothermal Energy Studies

National Science Foundation

1800 G. Street

Washington, DC 20550

Morton C. Smith

Los Alamos Scientific Laboratory

P.0. Box 1663

Los Alamos, NM 87544
No. of

Copies

K. P. Ananth

Midwest Research Institute

425 Volker Boulevard

Kansas City, MO 64110

K. T. Semrau

Stanford Research Institute

333 Ravenswood Avenue

Men lo Park, CA 94025

Gerald Katz

Geothermal Division

U.S. Department of Energy

San Francisco Operations Office

1333 Broadway

Oak land, CA 94612

Douglas Boehm

U.S. Department of Energy

Division of Environmental Control

Technology

Washington, DC 20545

Mike Butler

ICF Inc.

$1850 \mathrm{~K}$ Street N.W.

Washington, DC 20006

Robert Hartley

U.S. Environmental Protection Agency

Industrial Environmental Research Laboratory

Cincinnati, $\mathrm{OH} 45268$

W. L. Johnson

U.S. Forest Service

324 25th Street

Ogden, UT 84401

Steve Massie

Procon International

50 UOP Plaza

Des Plaines, Illinois 60016 
No. of

Copies

Bob Babione

Coury and Associates

7625 W. 5 th Avenue Upper Dome

Lakewood, CO 80226

Joe Kuebler

Dames and Moore

125 E. Victoria St.

Suite $F$

Santa Barbara, CA 93101

Jack Baly

Eastman Kodak Company

B69

Rochester, NY 14650

F. C. Brown

EIC Corporation

55 Chapel Street

Newton, MA 02158
No. of

Copies

ONSITE

DOE Richland Operations Office Programs Division

H. E. Ransom

29 Pacific Northwest Laboratory

M. Y. Ballinger

J. W. Currie (2)

S. A. Weakley

K. D. Wells (10)

Economics Library (8)

Technical Information (5)

Publishing Coordination KE (2) 